С.В. Мурадов

Е.А. Девятова

Т.П. Головина

\title{
Лабораторный практикум
} по дисциплине «Микротехника» 


\section{С.В. Мурадов \\ Е.А. Девятова \\ Т.П. Головина}

\section{ЛАБОРАТОРНЫЙ ПРАКТИКУМ ПО ДИСЦИПЛИНЕ «МИКРОТЕХНИКА»}


УДК 57.086.15(075.8)

ББК 28 ся 73

M91

Рекомендовано Учебно-методическим советом

ФГБОУ ВО «Камчатский государственный университет им. В. Беринга»

в качестве лабораторного практикума для бакалавров,

обучающихся по направлению подготовки «Биология»

\section{Рецензент}

Захарихина Лалита Валентиновна, доктор биологических наук

Мурадов С.В., Девятова Е.А., Головина Т.П.

М91 Лабораторный практикум по дисциплине «Микротехника» : учеб.-метод. пособие / С.В. Мурадов, Е.А. Девятова, Т.П. Головина. - Чебоксары: ИД «Среда», 2019. - 84 с.

\section{ISBN 978-5-6043435-2-4}

В практикуме изложены методы световой микроскопии, приемы изготовления временных и постоянных микропрепаратов, способы фиксации и окрашивания микропрепаратов. Практикум включает 6 лабораторных работ, содержащих полные методические указания для самостоятельной работы студентов на лабораторных занятиях, а также материалы для самопроверки и подготовки к практическим занятиям по дисциплине.

Практикум предназначен для студентов, обучающихся по направлению подготовки 06.03.01 «Биология».

DOI $10.31483 / \mathrm{a}-97$

ISBN 978-5-6043435-2-4
(C) C.В. Мурадов, Е.А. Девятова, Т.П. Головина

(С) ИД «Среда», 2019 


\section{ОГЛАВЛЕНИЕ}

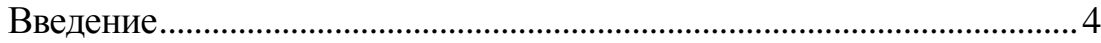

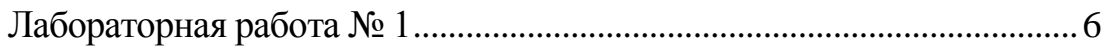

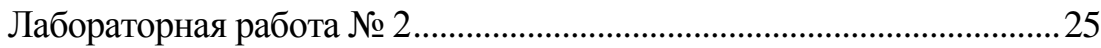

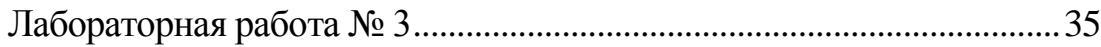

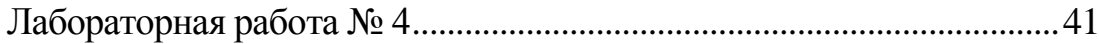

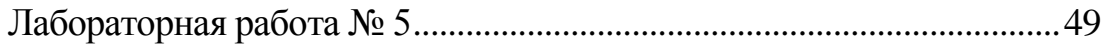

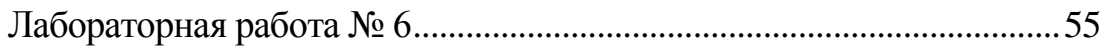

Вопросы к практическим занятиям ......................................................59

Организация самостоятельной работы студентов ..................................63

Методические рекомендации к различным видам самостоятельной

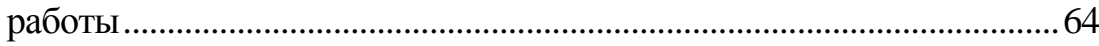

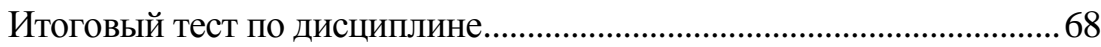

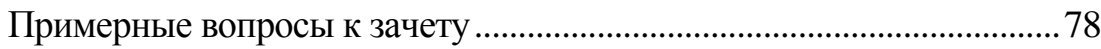

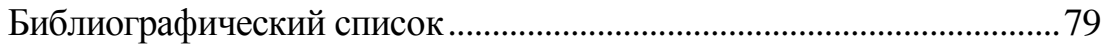




\section{ВВЕДЕНИЕ}

Микротехника - это совокупность методов и приёмов, применяемых для получения микроскопических препаратов с последующим изучением их с помощью микроскопа. Микротехника включает: подготовку растительных и животных объектов к микроскопическому исследованию и его проведение, изготовление временных и постоянных препаратов; гистохимические и цитохимические исследования. Освоение методики и техники получения постоянных и временных препаратов является необходимым условием для проведения биологических исследований.

Основным содержанием микротехники является технология приготовления микропрепаратов для всех разновидностей световой и электронной микроскопии, а также цитохимические, иммуноцитохимические исследования клеточных процессов, овладение устройством и использование микроскопии. В результате освоения дисциплины студент должен знать основные этапы приготовления микропрепаратов (фиксация, окраска, заключение, микротомирование, монтаж срезов) и элементы приготовления ультрапрепаратов (пластификация, ультрамикротомирование, напыление осмием и др.). В результате освоения дисциплины студент должен уметь осуществлять забор биологических материалов, этикетировку, фиксацию проб, парафинирование, нарезку на микротоме, окраску основными красителями, монтаж микропрепаратов и их микроскопическое исследование. Умение студентов обеспечивается навыками работы с зоологическими и ботанические объектами при заборе тканей и их исследовании с применением секционной техники (скальпели, ножницы), измерительной аппаратуры (весы, пипетки, линейки, циркули и др.), соблюдением правил асептики и антисептики и умением проводить дезинфекционные мероприятия, умением использовать вытяжной шкаф и вентиляцию, соблюдением мер безопасности при работе с агрессивными и токсичными жидкостями и материалами.

В ходе изучения курса микротехники реализуются следующие задачи:

1. Развитие у студентов умения ориентироваться и грамотно подходить к выбору метода исследования и необходимого оборудования и реактивов; 
2. Формирование практических навыков самостоятельной работы на лабораторном оборудовании;

3. Формирование практических навыков составления химических реактивов, необходимых для приготовления определенных препаратов.

В процессе изучения курса микротехники студенты освоят различные методы подготовки биологического материала для исследований с помощью светового микроскопа, методику и технику приготовления временных препаратов, постоянных микротомных препаратов, давленных препаратов, научатся переводить временные препараты в постоянные, овладеют навыками составления фиксаторов и красителей. Полученные в ходе изучения курса микротехники навыки помогут будущим специалистам в профессиональной деятельности в биологических лабораториях разного профиля. 


\section{ЛАБОРАТОРНАЯ РАБОТА № 1}

\section{Тема: «Устройство микроскопа и его применение»}

Цель занятия: ознакомиться и обсудить современные методы микроскопических исследований. Отработать важнейшие аспекты использования микроскопа для исследовательских целей.

\section{Оборудование, материаль:}

1) микроскопы бинокулярные;

2) предметные и покровные стекла;

3) иммерсионное масло;

4) спирто-эфирная смесь;

5) спирт 96\%;

6) ватные тампоны;

7) деревянные палочки.

\section{Самостоятельная работа студентов}

1. Ознакомиться с устройством микроскопа, внимательно прочитать описание, сравнить с действующим микроскопом. Выписать назначение и состав систем микроскопа.

2. Внимательно прочитать методику установки освещения по Келеру и отработать при наблюдении имеющихся препаратов.

3. Внимательно прочитать методику использования иммерсионных объективов, настроить микроскоп по Келеру, показать преподавателю.

4. По окончанию работы проверить чистоту микроскопа, очистить его предварительно прочитав описание методики.

Микроскоп является одним из основных инструментов, позволяющим оценивать состояние ткани на клеточном уровне в цитологических исследованиях. Он должен выполнять следующие функции:

- увеличивать изображение препарата в диапазоне, позволяющем оценить как группу клеток, так и обеспечивать возможность выделения одной клетки в поле зрения;

- обеспечивать точную цветопередачу окрашенного препарата, а также геометрические параметры (морфология) объектов препарата;

- воспроизводить изображение препарата с разрешением элементов, позволяющим определить патологию как по группе клеток, так и собственно по клетке и ее окружению. 
Для выполнения этих функций необходимо соблюдать ряд правил, среди которых первое место занимает настройка освещения правильная координация (положение) осветителя проходящего света относительно оптической оси микроскопа. От этого зависит цветопередача и геометрия объектов препарата, а также разрешающая способность и качество изображения в микроскопе.

\section{Назначение и конструкция микроскопа:}

Микроскоп представляет собой сложную оптико-механическую конструкцию. В отличие от лупы он имеет как минимум двухступенчатое увеличение.

На рис. 1 представлена схема современного биологического микроскопа проходящего света. Микроскоп условно можно разделить на три части:

1) осветительную;

2) воспроизводящую;

3) визуализирующую.

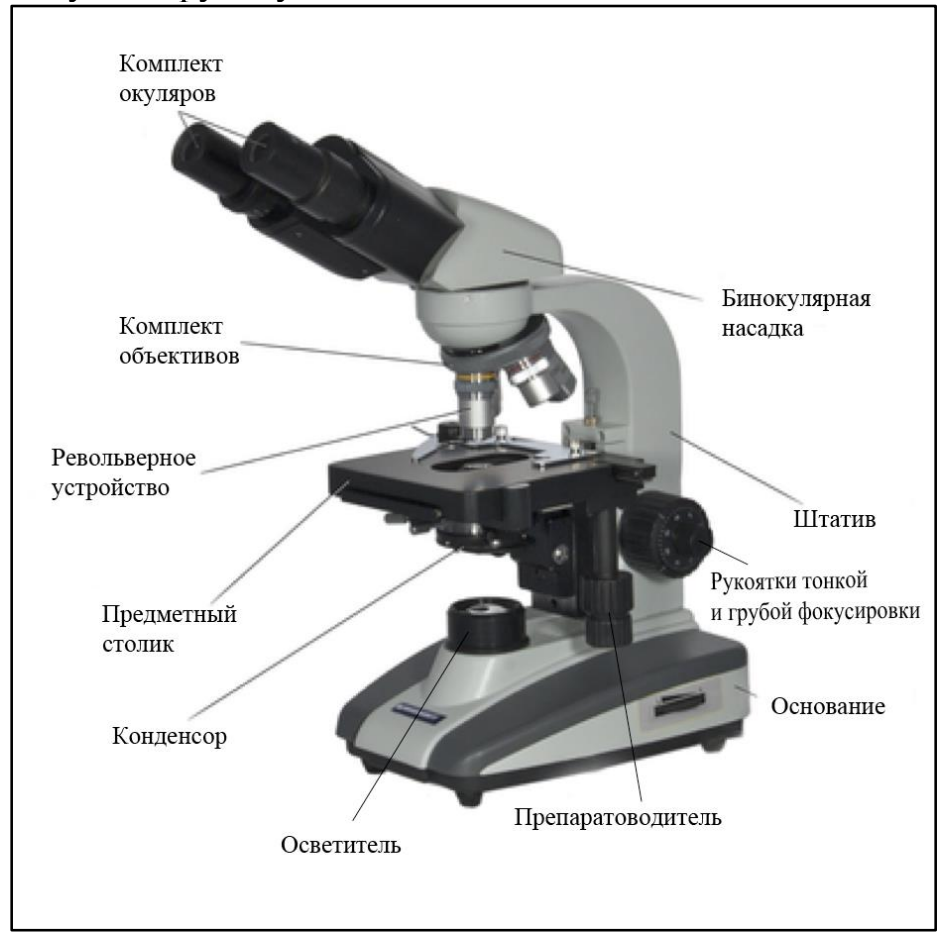

Рис. 1. Микроскоп с бинокулярной насадкой 
Между осветительной и воспроизводящей частями находится так называемая плоскость предмета, на которой располагается препарат, - это предметный стол. Между воспроизводящей и визуализирующей частями расположена плоскость изображения. Эту плоскость можно формализовать, если взять белый лист бумаги и расположить его на расстоянии, определяющем длину тубуса микроскопа. Длина тубуса - это оптическое расстояние между плоскостями предмета и изображения. Обычно эта величина маркируется на корпусе объектива (160 мм или «со»).

Осветительная часть представляет собой осветительную систему, состоящую из источника света, создающего световой поток; коллектора, расположенного в непосредственной близи к источнику света; конденсора, который расположен вблизи препарата. Задачей осветительной части является создание такого светового потока, который должен пройти через препарат и не нарушить его оптических свойств (поглощение, отражение, цветопередачу) и геометрических параметров (контура, размеров).

Воспроизводящая часть состоит из одного элемента - объектива, но это основной элемент микроскопа. Задачей объектива является создание основного увеличенного изображения препарата с максимальной достоверностью по форме, цвету и разрешению элементов.

Визуализирующяая часть микроскопа включает в себя две функции:

- дополнительное увеличение созданного объективом изображения препарата;

- создание изображения на носителе информации (глаз, фотопленка, видеокассета, монитор).

Дополнительное увеличение может быть получено следующими способами:

- окуляром, т. е. оптическим элементом, проектирующим изображение препарата, созданное объективом, на сетчатку глаза наблюдателя;

- системой «окуляр - оптовар» (оптовар - это система дополнительного увеличения, расположенная между объективом и окуляром);

- адаптером, т.е. дополнительным элементом, предназначенным для соединения камеры документирования с микроскопом;

- системой «оптовар - адаптер». 
Общее увеличение микроскопа определяется по следующей формуле:

$$
\begin{gathered}
\text { Общее } \\
\text { увеличение } \\
\text { микроскопа }
\end{gathered}=\begin{gathered}
\text { увеличение } \\
\text { объектива }
\end{gathered} \times \begin{gathered}
\text { увеличение } \\
\text { окуляра }
\end{gathered} \times \begin{gathered}
\text { дополнительное } \\
\text { увеличение } \\
\text { системы }
\end{gathered}
$$

Если есть система документирования, то, как правило, обычный окуляр не участвует в построении увеличении изображения. Зато в такой системе находятся адаптеры: это видеоадаптеры, фотоадаптеры, а также расположенные в них специальные системы типа фотоокуляров и гамалов, т. е. отрицательных окуляров. В этом случае формула приобретает следующий вид:

$\begin{gathered}\text { Общее } \\ \text { увеличение } \\ \text { микроскопа }\end{gathered}=\begin{gathered}\text { увеличение } \\ \text { объектива }\end{gathered} \times \begin{gathered}\text { увеличение } \\ \text { адаптера }\end{gathered} \times \begin{gathered}\text { дополнительное } \\ \text { увеличение } \\ \text { системы }\end{gathered}$

К основным оптическим элементам микроскопа относятся объектив, окуляр и конденсор.

Объектив. Объективы микроскопа представляют собой оптические системы, предназначенные для построения микроскопического изображения в плоскости изображения с соответствующим увеличением, разрешением элементов, точностью воспроизведения по форме и цвету объекта исследования. Они имеют сложную оптико-механическую конструкцию, которая включает несколько одиночных линз и компонентов, склеенных из двух или трех линз. Количество линз обусловлено решаемыми объективом задачами. Чем выше качество изображения, даваемое объективом, тем сложнее его оптическая схема. Объективы с числовой апертурой более 0,50 имеют пружинящую оправу для предотвращения порчи как препарата, так и фронтального компонента (первой линзы) объектива. Это связано с его небольшим рабочим расстоянием и малой глубиной резкости. Глубина резкости - это та толщина (глубина) на объекте, которую можно просмотреть без дополнительной перефокусировки объектива. Чем больше числовая апертура объектива, тем меньше глубина резкости. 
В табл. 1 представлены основные обозначения для применяемых в практической медицине микроскопов отечественного производства и микроскопов последнего поколения.

Таблица 1 - Маркировка объективов

\begin{tabular}{|c|c|c|}
\hline Параметр & Обозначение & Значение \\
\hline \multirow{3}{*}{$\begin{array}{l}\text { Тип оптической } \\
\text { коррекции } \\
\text { объектива }\end{array}$} & $\begin{array}{l}\text { CP-Achromat, } \\
\text { Стигсмахромат }\end{array}$ & $\begin{array}{c}\text { Объективы ахроматические } \\
\text { плоского поля }\end{array}$ \\
\hline & $\begin{array}{l}\text { PL (A-Plan, Achro- } \\
\text { plan, N-Plan) }\end{array}$ & $\begin{array}{c}\text { Объективы ахроматические / } \\
\text { апохроматические плоского } \\
\text { поля }\end{array}$ \\
\hline & $\begin{array}{l}\text { Plan-Neofluar, } \\
\text { PL-Fluotar, } \\
\text { Микрофлюар }\end{array}$ & $\begin{array}{c}\text { Флюоритовые системы объек- } \\
\text { тивов (полуапохроматическая } \\
\text { коррекция объективов } \\
\text { с повышенным разрашением } \\
\text { и увеличенными числовыми } \\
\text { апертурами) } \\
\end{array}$ \\
\hline $\begin{array}{c}\text { Основные } \\
\text { технические } \\
\text { параметры } \\
\end{array}$ & $40 x / 0,65$ & $\begin{array}{c}\text { Увеличение/числовая } \\
\text { апертура объектива }\end{array}$ \\
\hline \multirow{2}{*}{ Длина тубуса } & 160 & $\begin{array}{l}\text { Конечная длина } \\
\text { тубуса - } 160 \text { мм }\end{array}$ \\
\hline & $\infty$ & Длина тубуса - $\infty$ \\
\hline \multirow{3}{*}{$\begin{array}{l}\text { Исправление } \\
\text { объектива } \\
\text { на толщину } \\
\text { покровного } \\
\text { стекла }\end{array}$} & 0 & $\begin{array}{l}\text { Объектив рассчитан на работу } \\
\text { только без покровного стекла }\end{array}$ \\
\hline & 0,17 & $\begin{array}{c}\text { Объектив рассчитан на работу } \\
\text { только с покровным стеклом }\end{array}$ \\
\hline & - & $\begin{array}{c}\text { Объектив рассчитан на работу } \\
\text { с покровным стеклом } \\
\text { и без покровного стекла } \\
\end{array}$ \\
\hline \multirow[b]{2}{*}{ Иммерсия } & Нет маркировки & «Сухие» объективы \\
\hline & $\begin{array}{c}\text { «МИ», «Oil», } \\
\text { маркировка черной } \\
\text { полосы во } \\
\text { фронтальной части } \\
\text { объектива } \\
\end{array}$ & Объект масляной иммерсии \\
\hline
\end{tabular}




\begin{tabular}{|c|c|c|}
\hline & $\begin{array}{c}\text { «И», «W», марки- } \\
\text { ровка белой полосы } \\
\text { во фронтальной ча- } \\
\text { сти объектива }\end{array}$ & Объектив водной иммерсии \\
\hline & $\begin{array}{c}\text { «ГИ», «Glyz», } \\
\text { маркировка } \\
\text { красной полосы во } \\
\text { фронтальной части } \\
\text { объектива } \\
\end{array}$ & $\begin{array}{c}\text { Объективы глицериновой им- } \\
\text { мерсии }\end{array}$ \\
\hline \multirow{4}{*}{$\begin{array}{c}\text { Работа объектива } \\
\text { в составе } \\
\text { модулей методов } \\
\text { контрастирова- } \\
\text { ния }\end{array}$} & $\begin{array}{c}\text { Общий цвет } \\
\text { маркировки на кор- } \\
\text { пусе черный }\end{array}$ & $\begin{array}{c}\text { Объективы работают } \\
\text { по методу светлого поля }\end{array}$ \\
\hline & $\begin{array}{c}\text { Маркировка «Ф», } \\
\text { «РА», общий цвет } \\
\text { маркировки } \\
\text { зеленый }\end{array}$ & Фазовый объектив \\
\hline & $\begin{array}{c}\text { Маркировка «Л», } \\
\text { «Fluorez» }\end{array}$ & $\begin{array}{c}\text { Люминесцентный объектив } \\
\text { (минимум собственной } \\
\text { люминесценции) }\end{array}$ \\
\hline & $\begin{array}{c}\text { Маркировка «П», } \\
\text { «Роl», общий цвет } \\
\text { маркировки } \\
\text { красный }\end{array}$ & $\begin{array}{c}\text { Поляризационные объективы } \\
\text { (минимум натяжения) }\end{array}$ \\
\hline
\end{tabular}

Все основные сведения об объективе наносятся на его корпус. Надпись в общей сложности делится на три части:

- тип оптической коррекции - уровень исправления качества изображения объектива (ахроматы - исправление всех искажений для одной длины волны - зеленой; апохроматы - исправление всех искажений для трех длин волн - синей, зеленой, красной; план объективы плоского поля);

- основные технические параметры объектива, необходимые для расчета увеличения и разрешающей способности;

- условия работы объектива - длина тубуса объектива (следовательно, и микроскопа), коррекция объектива при работе с соответствующим покровным стеклом и типом иммерсионной жидкости, работа объектива в составе модулей методов контрастирования. 
Окуляр. Окуляр относится к оптической системе визуализирующей части микроскопа и предназначен для построения микроскопического изображения на сетчатке глаза наблюдателя. Он создает дополнительно увеличенное изображение объекта и работает как лупа. В общем виде окуляры состоят из двух групп линз: глазной (ближайшей к глазу наблюдателя) и полевой (ближайшей к плоскости построенного объективом изображения).

Характеристикой окуляра является его линейное и угловое поля, а также окулярное число. Чем больше окулярное число при одном и том же увеличении, тем выше класс окуляра, особенно если он скорректирован для работы с объективом плоского поля. Диоптрийная наводка окуляра - это настройка одного глаза на резкое изображение элементов, находящихся в плоскости изображения. Это могут быть собственно изображения препарата или окулярный микрометр (шкала), установленные внутри окуляра.

Окуляры Гюйгенса - простейшие окуляры с максимальным линейным полем 18 мм и хроматической разностью увеличения $0 \%$; состоит, как минимум, из двух линз.

Компенсационные окуляры (маркировка «К») предназначены для компенсации цветного искажения, вносимого объективами, которые имеют расчетное значение хроматической разности увеличения более $0,3 \%$.

Осветительная система микроскопа представляет собой систему линз, диафрагм и зеркал, которая обеспечивает равномерное освещение объекта и полное заполнение апертуры объектива. Она состоит из двух частей: источника света с коллектором и конденсора. При встроенной осветительной системе проходящего света коллекторная часть расположена вблизи источника света в основании микроскопа и предназначена для увеличения размера светящегося тела. Для настройки осветительной системы коллектор может быть выполнен подвижным, что обеспечивает его перемещение вдоль оптической оси. Вблизи коллектора располагается ирисовая полевая диафрагма микроскопа, которая в закрытом состоянии должна быть резко видна в плоскости предмета вместе с резким изображением препарата.

Конденсор. Оптическая система конденсора предназначена для увеличения количества света, поступающего в микроскоп. Конденсор располагается между препаратом (предметным столиком) и осветителем (источником света). Чаще всего в учебных и 
простых микроскопах конденсор может быть несъемным и неподвижным. В остальных случаях он является съемной частью и при настройке освещения перемещается вдоль оптической оси для фокусировки и перпендикулярно оптической оси для центрировки. При конденсоре всегда находится осветительная апертурная ирисовая диафрагма.

Конденсор является одним из основных элементов, позволяющих работать с микроскопом при различных освещении и контрастировании:

1) косое освещение обеспечивается смещением осветительной апертурной диафрагмы конденсора относительно оптической оси микроскопа;

2) темное поле создается за счет максимального перекрытия осветительной апертуры конденсора;

3) фазовый контраст обеспечивается проходящим через препарат потоком света, созданный кольцевой диафрагмой, которая расположена в плоскости осветительной апертурной диафрагмы. При этом изображение светового кольца вписывается в фазовое кольцо объектива.

Бывают следующие виды конденсоров:

- Конденсор Аббе состоит из двух линз. Осветительная апертура конденсора A $=0,9 / 1,20^{1}$.

- Апланатический конденсор состоит из трех линз. Осветительная апертура $\mathrm{A}=0,9 / 1,40$.

- Ахроматический конденсор полностью исправлен в отношении хроматической и сферической аберраций. Диапазон осветительной апертуры - 0,8 - 0,9.

- Ахроматический апланатический конденсор обладает высоким качеством изображения. Осветительная апертура $\mathrm{A}=0,9$.

Наиболее часто встречается отечественный апланатический конденсор прямого и косого освещения ОИ-14: числовая апертура фронтальной части - 1,4; числовая апертура большого поля - 0,3; пределы перемещения ирисовой апертурной диафрагмы перпендикулярно оптической оси микроскопа для получения косого освещения - \pm 10 мм; пределы угла разворота ирисовой апертурной диафрагмы - от 0 до $150^{\circ}$. Конденсор используется в микроскопах серии «Биолам» и «Микмед 1 ». 


\section{Механические части микроскопа}

Основным конструктивно-механическим блоком микроскопа является штатив, который включает в себя основание и тубусодержатель.

Основание представляет собой блок, на котором крепится весь микроскоп. В простых микроскопах на основание устанавливают осветительные зеркала или накладные осветители. В более сложных моделях осветительная система встроена в основание с блоком питания или без него.

Тубусодержатель представляет собой блок, на котором расположены:

- узел крепления светоделительных элементов (блоков для отраженного света; блоков светофильтров люминесцентного осветителя);

- револьверное устройство для крепления объективов;

- фокусировочный механизм грубой и точной настройки микроскопа на резкость;

- узел крепления сменных предметных столиков;

- узел крепления, а также фокусировочного и центрировочного перемещения конденсора;

- узел крепления сменных насадок (визуальных, фотографических, телевизионных, различных передающих устройств).

Одним из основных и точных элементов, входящих в механическую часть микроскопа, является предметный столик, предназначенный для крепления препарата и его фиксации в определенном положении под микроскопом. Столики бывают неподвижные, координатные, поворотные (на ограниченный угол) и вращающиеся (центрируемые и нецентрируемые). На столике устанавливаются препаратодержатели и препаратоводители.

\section{Работа с микроскопом}

Очень важно уметь правильно обращаться с микроскопом: настраивать его для проведения исследований в разном свете; знать особенности оптической схемы; работать с иммерсионными объективами. Чтобы продлить срок службы этого прибора, необходимо правильно с ним обращаться и чистить. В этом подразделе мы рассмотрим основные моменты эксплуатации микроскопа, знать которые должен каждый специалист, работающий с этим прибором. 
Настройка освещения по Келеру: принцип Келера заключается в том, что осветительная система микроскопа (источник света, коллектор, конденсор) устанавливается на одну оптическую ось с собственно оптикой микроскопа, объективом, окуляром. Для этого имеются две материальные диафрагмы, которые мы физически видим в отличие от оптической оси, которую мы не видим. Это полевая диафрагма, установленная на штативе микроскопа вблизи осветителя (источника света и коллектора), и апертурная диафрагма, смонтированная внутри конденсора. Порядок настройки заключается в следующем:

1. Получают резкое изображение препарата:
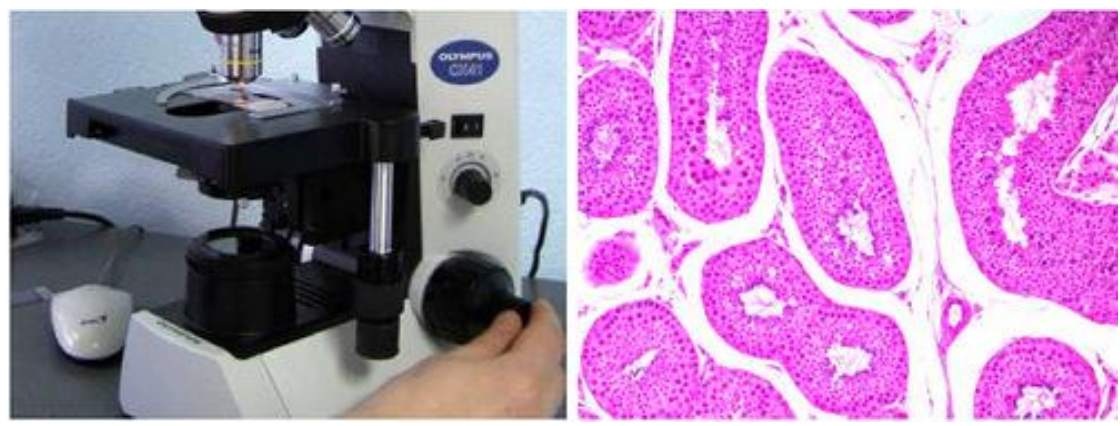

2. Прикрывают полевую диафрагму осветителя.
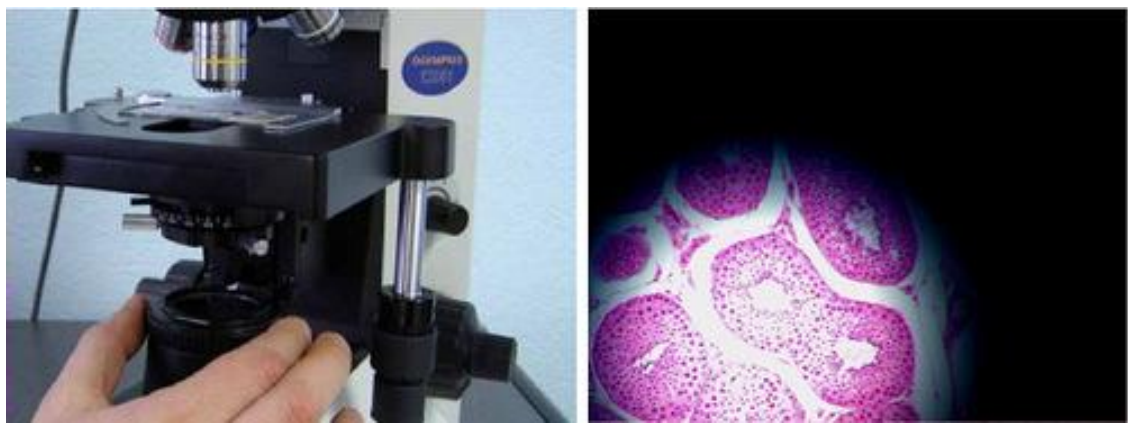

3. С помощью фокусировочного механизма конденсора добиваются резкого изображения краев полевой диафрагмы. С помощью центрировочных винтов конденсора приводят изображение полевой диафрагмы в центр поля видения. 


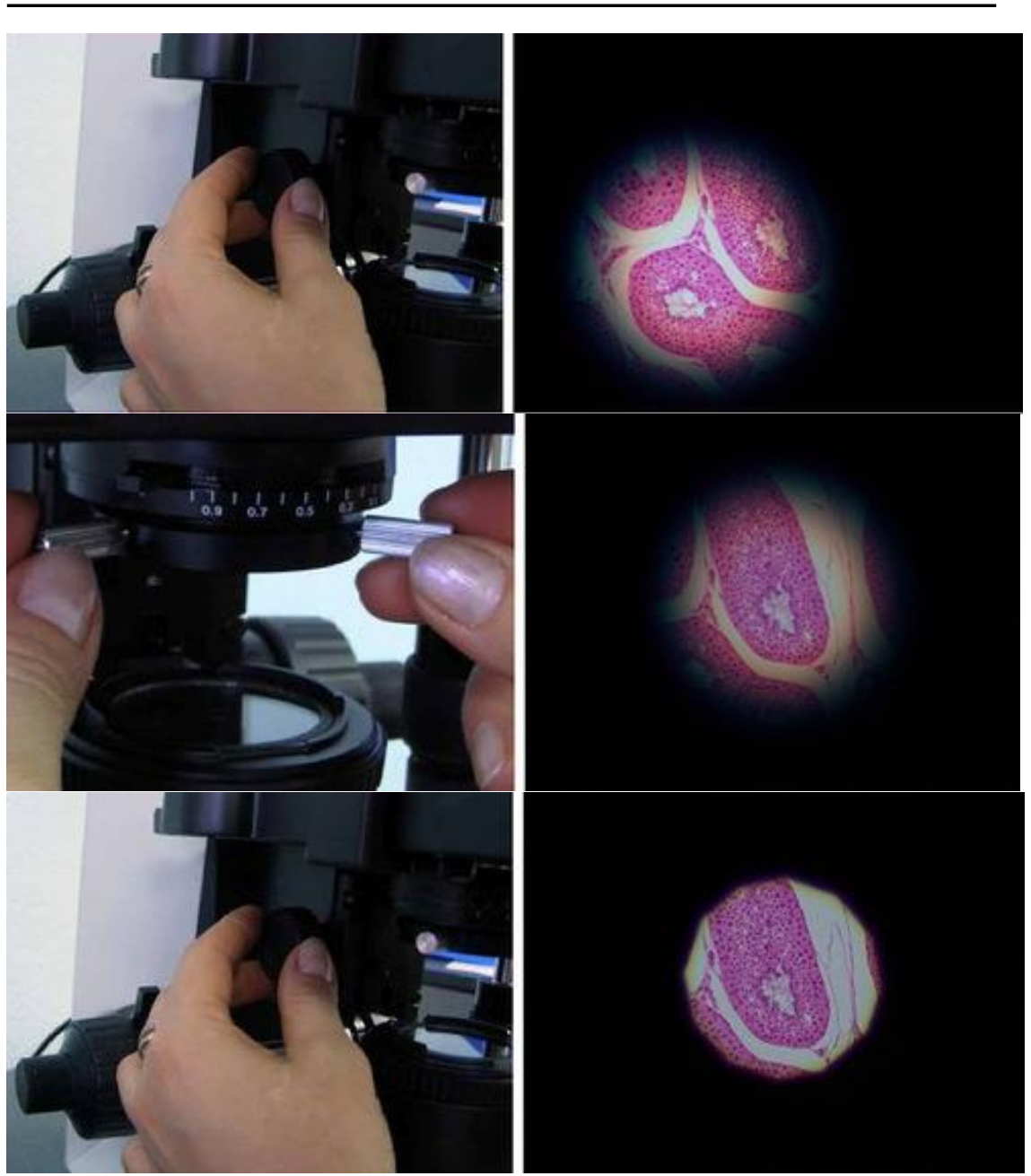

4. Раскрывают полевую диафрагму до размера поля видения. 

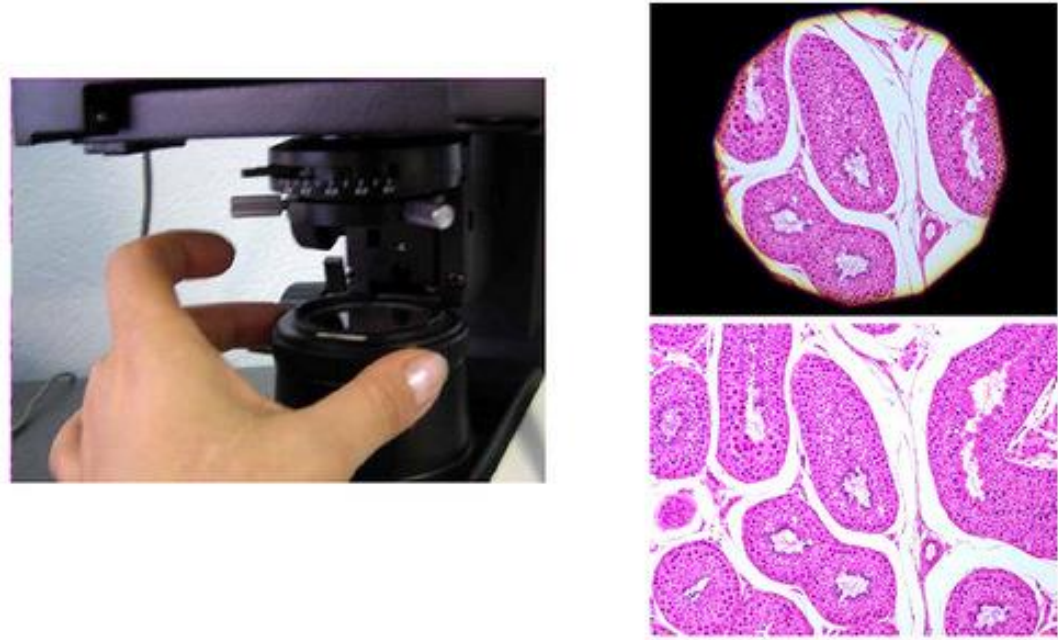

5. Открывают апертурную диафрагму конденсора по выходному зрачку объектива и, наблюдая за ярким пятном в микроскопе, открывают апертурную диафрагму в размер этого пятна. Для улучшения контраста изображения рекомендуется открыть апертурную диафрагму конденсора на 80 \% относительно выходного зрачка объектива.
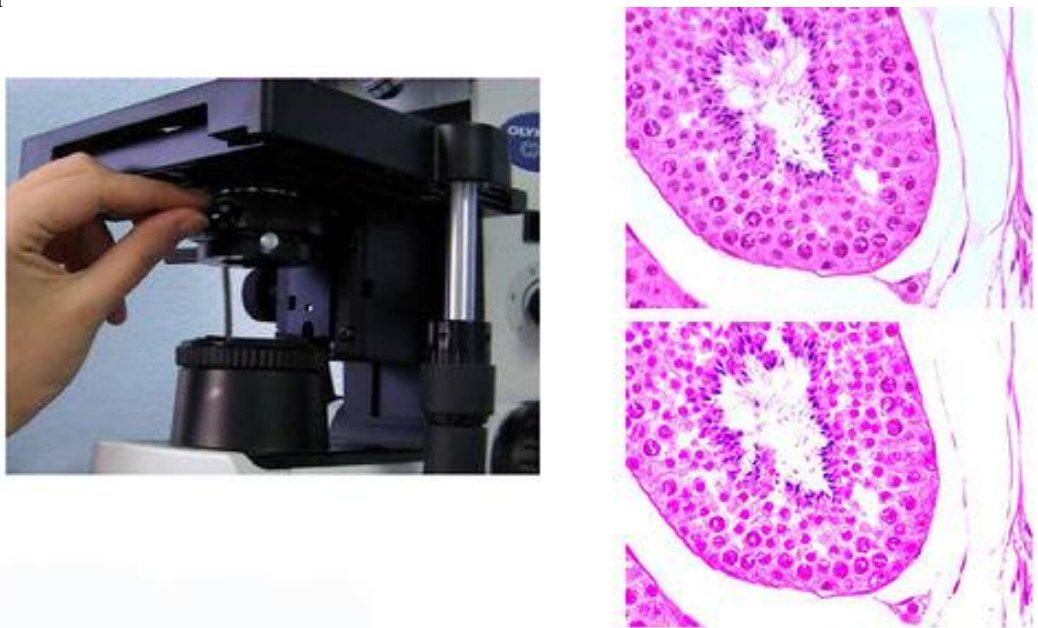

Необходимо помнить, что при появлении бликов, рефлексов, блёскости, снижении контраста следует проверить правильность 
настройки освещения в указанном выше порядке. Все операции проводятся при сфокусированном на препарат микроскопе. При работе с объективами больших увеличений (от 20х и выше) рекомендуется применять конденсор с числовой апертурой $\mathrm{A}=$ $0,9 / 1,25(1,4)$ и объективами $10 \mathrm{x}$ и меньше - конденсор $\mathrm{A}=0,3 \mathrm{c}$ линзой большого поля.

\section{Работа с иммерсионными объективами}

Качество изображения, параметры и оптическую конструкцию иммерсионных объективов рассчитывают и выбирают с учетом толщины слоя иммерсии, которую рассматривают как дополнительную линзу с соответствующим показателем преломления. Иммерсионная жидкость, расположенная между объектом и фронтальным компонентом объектива, увеличивает угол, под которым рассматривают объект (апертурный угол). Числовая апертура без иммерсионного (сухого) объектива имеет значение только до 1,0. При этом разрешающая способность такого объектива порядка 0,3 мкм для основной длины волны. Числовая апертура иммерсионного объектива для медико-биологических исследований доходит до 1,45 в зависимости от показателя преломления иммерсии и технологических возможностей изготовления фронтальной линзы, разрешающая способность порядка 0,12 мкм. Иммерсионные объективы больших увеличений имеют небольшое фокусное расстояние $-1,5-2,5$ мм при свободном рабочем расстоянии $0,1-0,3$ мм (расстояние от плоскости препарата до оправы фронтальной линзы объектива).

Иммерсия (от лат. immersio - погружение) - это жидкость, заполняющая пространство между объектом наблюдения и специальным иммерсионным объективом, также может заполнять пространство между конденсором и предметным стеклом. Ее применяют в тех случаях, когда требуется повысить разрешающую способность микроскопа или она находится в технологическом процессе микроскопирования. При этом: повышается видимость за счет увеличения разности показателя преломления в промежутке между объективом и объектом; увеличивается глубина просматриваемого слоя, которая зависит от показателя преломления среды. Кроме того, иммерсионная жидкость уменьшает количество рассеянного света, устраняя блики от объекта. При этом устраняются неизбежные потери света при попадании его в объектив. 
Порядок работы с объективом масляной иммерсии следующий.

1. Настраивают осветительную систему микроскопа по принципу Келера для работы методом светлого поля.

2. Выводят из хода лучей сухой объектив.

3. На препарат капают иммерсионное масло, при этом желательно немного смазать фронтальную линзу объектива.

4. Вводят в ход лучей иммерсионный объектив (50xМИ или 100хМИ), фиксируют его.

5. Опускают объектив до соприкосновения с каплей иммерсионной жидкости, затем, наблюдая в микроскоп, с помощью рукояток грубой и точной фокусировки настраивают резкость.

После работы надо обязательно чистить фронтальную (первую) линзу объектива и конденсора.

\section{Уход за микроскопом}

В настоящее время лаборатории оснащены самыми разнообразными моделями биологических микроскопов как отечественного, так и зарубежного производства. Чтобы продлить срок службы микроскопов, выработаны общие правила обращения, настройки и ухода за ними.

1. Микроскоп должен храниться в чехле, лучше полиэтиленовом (под стеклянным колпаком), либо в ящике или шкафу.

2. Для предохранения попадания пыли внутрь микроскопа окуляры должны быть вставлены в окулярные трубки, объективы ввинчены в гнезда револьверного устройства. Если отсутствуют окуляры, то на окулярные трубки необходимо одеть бумажный чехол, а в гнездо вставить заглушку или заклеить широким скотчем.

3. Вынимая микроскоп из ящика, снимая с полки, а также при переноске с места на место, прибор необходимо одной рукой держать за штатив, а другой - за основание.

4. Необходимо оберегать микроскоп от механических ударов.

5. Каждый объектив должен быть ввинчен до конца в гнездо револьверного устройства и четко фиксироваться в ходе лучей при рабочем состоянии микроскопа.

6. Необходимо предохранять фронтальные линзы объективов и конденсора, а также глазные линзы окуляров от соприкосновения с различными реактивами.

7. Нельзя без необходимости снимать бинокулярную насадку и касаться пальцами поверхности тубусной линзы. 
8. Нельзя касаться любой стеклянной поверхности микроскопа пальцами, так как останутся жирные следы. После этого требуется проводить внеплановую чистку оптики, которая может повлечь за собой повреждение просветляющих поверхностей.

9. Категорически запрещается снимать «рубашку» (металлический корпус) объектива и разбирать его.

10. Если с микроскопом не работают, объективы должны быть опущены (в ход лучей должен быть установлен объектив малого увеличения). При этом они не должны касаться предметного столика.

11. Перед началом или в конце работы рекомендуется оценить чистоту основных оптических поверхностей объектива, окуляров и конденсора микроскопа и при загрязнении немедленно их очистить.

Для продления срока службы ламп в осветителях рекомендуется не подвергать их резким перепадам напряжения и перед включением и выключением переводить регулятор накала нити лампы (реостат) в минимальное положение. Осветители без регулятора накала (реостата) для продления срока службы лампы рекомендуется реже выключать.

13. Раз в полгода представители сервисной технической службы должны чистить и смазывать микроскоп.

Если на оптической поверхности проявляются пыль и грязь, в плоскости предмета может появляться «инородное» тело; изображение становится нечетким, контраст - малым (серое изображение); в изображении появляются «провалы» («неспокойное» изображение); снижается разрешение (нельзя различить близко расположенные элементы объекта).

Место загрязнения можно найти, если определить его характер:

1) если хорошо видны «инородное» тело вместе с препаратом, то необходимо повернуть окуляр. Если грязь движется вместе с окуляром, то она находится в плоскости последней линзы окуляра. Если в окуляре установлена шкала, то грязь может осесть на поверхности пластинки (обычно со стороны последней линзы окуляра);

2) если «инородное» тело неявно проявляется, когда глаз чуть отодвигается от первой (глазной) линзы окуляра, значит, необходимо почистить эту линзу;

3) если «инородное» тело видно, но не двигается вместе с окуляром, необходимо подвинуть предметное стекло. Если «инородное» тело сдвинулось, надо почистить поверхность покровного стекла; 
4) если в плоскости предмета на объекте видны серые тени, разноцветные ореолы, неяркая грязь - это, скорее всего, дефект настройки освещения. Следует подвинуть вверх-вниз конденсор, проверить, в каком положении находится апертурная диафрагма, в центре ли расположен источник света. Можно провести настройку по Келеру;

5) если при движении конденсора грязь будет «размываться», а затем исчезнет, надо чистить первую поверхность (фронтальный компонент) конденсора, а также выходное защитное стекло, если осветительная система встроена в основание микроскопа;

6) если нельзя получить резкое изображение, снижены контраст и разрешение, изображение «неспокойное», необходимо снять объектив и прочистить его первую поверхность (фронтальный компонент);

7) снижение контраста (серое изображение с большим количеством рассеянного света) может возникнуть, если на тубусной линзе бинокулярной насадки появился отпечаток пальца. Надо вынуть окуляр и сбоку посмотреть в окулярную трубку микроскопа так, чтобы увидеть поверхность призмы и чуть дальше. Если отпечаток виден, необходимо снять бинокулярную насадку и очень осторожно протереть ее фланелевой тряпкой. Тубусную линзу не рекомендуется чистить спиртовыми смесями, так как на нее обычно наносят нестойкое просветляющее покрытие (в отличие от фронтальных компонентов объективов, конденсоров и глазных линз окуляров).

Самостоятельно можно чистить фронтальный компонент (первую поверхность) объектива, конденсора, глазную линзу окуляра, поверхность покровного стекла на препарате, обращенную к объективу, и поверхность предметного стекла, обращенную к конденсору, светофильтры, матовое стекло, внешнюю поверхность защитного стекла или коллектора на основании микроскопа при встроенной системе освещения, зеркало. Поверхности можно чистить специальными бумажными салфетками для чистки оптики и тряпочками для чистки очков. Однако поверхность фронтального компонента объективов может быть сильно загрязнена, и тогда чистить надо очень осторожно. 
Обязательный набор для чистки оптики включает следующие предметы:

1) деревянная палочка около 10 см длиной и диаметром 3-4 мм, с одной стороны заострена, а с другой - плоская. Дерево не царапает оптическую поверхность. Острым концом чистят оптические поверхности малого диаметра. Плоским концом меняют сетки в окуляре или выполняют любые другие операции с оптико-механическими узлами в микроскопе;

2) резиновая груша № 1. С ее помощью «выдувают» частички грязи и пыли из труднодоступных мест. Резиновая груша позволяет чистить поверхности, расположенные в глубине, или детали, которые нельзя чистить спиртом. Резиновый конец груши обеспечивает мягкость соприкосновения с оптическими деталями и не царапает их. Из-за небольших размеров грушу удобно держать в руке;

3) лупа $5 x-7 x$ для оценки чистоты поверхности фронтальной линзы. Также можно использовать окуляр, при этом последняя линза окуляра обращена к глазу наблюдателя;

4) хлопковая медицинская (не техническая!) вата. Техническая вата содержит комки и жесткие включения, которые при чистке или протирании царапают поверхность;

5) флакон с 96 \% спиртом. При использовании спирта с водой увеличивается время испарения спирта после протирания. Протирание спиртом с эфиром резко сокращает время испарения. От бензина появляются дополнительные разводы или поверхность совсем не очищается, так как нередко бензин содержит разнообразные масла.

Необходимо чистить объектив после работы с масляной (глицериновой и др.) иммерсией. В противном случае оставшееся и засохшее масло может стать дополнительной линзой, заполнившей всю поверхность фронтального компонента, или поверхностью в виде клина.

Процесс чистки проводят по нескольким этапам:

1. Объектив вывинчивают из револьверного устройства (или устанавливают в положение, удобное для чистки), из окулярной трубки вынимают окуляр.

2. Делают ватный тампон: слегка смачивают заостренный кончик палочки в спирте; из большого количества ваты, которое наматывают на кончик палочки, вытягивают небольшой кусок; кладут палочку с ватой на ладонь и скатывают тампон. 
3. Сухим тампоном одним движением снимают иммерсию с первой линзы объектива и металлической оправы, затем грязный тампон удаляют.

4. Делают новый ватный тампон.

5. Новый тампон смачивают в спирте, осторожно макая палочку и едва погружая ее во флакон.

6. Проверяют уровень влажности на запястье, потому что лишняя влага не должна попасть на фронтальную часть объектива. В противном случае линза может выпасть из оправы из-за расклейки. При большом количестве спирта тампон промокают сухой ватой.

7. Кругообразным движением от центра к краю без вдавливания линзы внутрь объектива аккуратно протирают поверхность линзы и металлическую оправу.

8. Проверяют, как выглядит фронтальная линза после первой чистки - направляют свет таким образом, чтобы он отражался от поверхности линзы. Также поверхность можно рассматривать с помощью лупы. Чистая поверхность должна быть без цветных разводов, полос, грязи. В противном случае операцию чистки необходимо повторить.

9. Перед окончательным протиранием чистым сухим тампоном дышат на поверхность, как бы смачивая ее слоем воды.

10. Кругообразным движением протирают поверхность.

11. Проводят окончательный контроль чистоты поверхности с помощью лупы.

12. Ввинчивают объектив на место в револьверное устройство.

Желательно выделить профилактический час, например в конце рабочей недели, и просматривать все объективы под лампочкой и с лупой в руках. Технология достаточно простая. На первую поверхность объектива направляют свет и оценивают ее чистоту. Если поверхность грязная, оптику чистят. Контролируют чистоту поверхности, рассматривая ее на свет со стороны резьбовой части объектива (последней поверхности объектива). Со стороны последней поверхности объектива резиновой «грушей» выдувают грязь.

Если объектив плохо вычищен, резко снизится контраст изображения, уменьшится четкость, резкость и разрешающая способность объектива, появится дополнительный рассеянный свет.

Грязь на металлических частях микроскопов обычно легко удалить ватой или тряпочкой, смоченными в спирте. Механические 
части микроскопа (револьверное устройство, фокусировочный механизм, предметный стол) из-за застывшей смазки или грязи требуют чистки и дополнительной смазки. Необходимо помнить, что каждый из перечисленных механизмов имеет свой тип смазки, обусловленный различными металлическими сплавами, из которых сделаны эти части.

\section{Вопросы для обсуждения:}

1. Перечислите функции, которые должен выполнять микроскоп.

2. Из каких частей состоит микроскоп?

3. Опишите устройство оптической системы микроскопа.

4. Из каких частей состоит механическая система микроскопа?

5. Какие существуют типы микроскопов?

6. Как настроить освещение по Келеру?

7. Опишите порядок работы с иммерсионными объективами.

8. Каковы общие правила обращения, настройки и ухода за микроскопом?

9. Как чистят микроскоп? 


\section{ЛАБОРАТОРНАЯ РАБОТА № 2}

Тема: «Техника изготовления временных препаратов»

Цель занятия: получить навыки приготовления временных препаратов.

\section{Оборудование, материаль:}

1. Микроскоп

2. Препаровальные иглы

3. Пинцеты

4. Предметные и покровные стекла

5. Скальпели

6. Бритвы

7. Фильтровальная бумага

8. Традесканция

9. Проростки злаковых в чашках Петри

10. Лук репчатый

11. Колбы с притертыми пробками

12. Обратный холодильник

13. Предметные и покровные стекла

14. Бумага фильтровальная

15. Спирт этиловый

16. Кислота уксусная ледяная

17. Хлороформ

18. Метиленовый синий

19. Кармин

20. Вода дистиллированная

\section{Самостоятельная работа студентов}

1. Ознакомиться со средами и объектами для прижизненных наблюдений.

2. Рассмотреть камеры для приготовления временных препаратов: камеру Ранвье и кольца Ван-Тигема.

3. Освоить методы приготовления временных препаратов: приготовить препарат чешуи лука, тычиночной нити традесканции, корешков злаковых методом изолирования отдельных тканей, окрасить раствором Люголя, сделать рисунок.

4. Ознакомиться с методикой приготовления давленных препаратов. 
Изучение объекта в живом состоянии - способ исследования, возникший в эпоху зарождения микроскопа и не потерявший своего значения до настоящего времени: микроскопирование живых клеток позволяет выяснить их физиологическое состояние, функции, а также реакции на различные воздействия. Изучение живых клеток - это и хороший способ проверить правильность результатов, полученных после фиксации объекта.

Микроскопирование живого объекта предполагает в качестве обязательного условия приготовление препарата временного типа; при этом клетки и ткани приходится, как правило, отделять от растения и погружать в новую, несвойственную им среду. Хирургическое вмешательство и новая для них среда легко могут вызвать нарушения в физиологическом состоянии клеток, поэтому главное правило в работе - добиться таких условий приготовления препарата и его последующего микроскопирования, при которых нарушение строения клеток и процессов их жизнедеятельности было бы минимальным. Необходимость обеспечения этих условий ограничивает число объектов, доступных изучению.

\section{Среды и объекты для прижизненных наблюдений}

1. Объекты, которые можно микроскопировать в природной среде без предварительного препарирования или при незначительном хирургическом вмешательстве.

К этой категории объектов в первую очередь относятся организмы, обитающие в воде, или их части: одноклеточные водоросли, нитевидные образования конъюгат, зеленые, бурые и красные водоросли, гифы растущих в воде грибов, клетки дрожжей, междоузлия харовых водорослей, протонема и однослойные листья мхов.

Удобны для прижизненных наблюдений также листья водных растений, например листья Elodea, состоящие из двух слоев клеток. Молодые листья осторожно отделяют острой бритвой или тонкими острыми ножницами и микроскопируют в природной среде. К этой же категории можно отнести корневые волоски водных растений, образующих свободно выступающие в воду корни. Молодые корни этих растений, густо покрытые корневыми волосками, осторожно отделяют при помощи ножниц, помещают в каплю воды на предметном стекле и закрывают покровным стеклом, под которое подкладывают с двух сторон небольшие осколки покровного стекла. 


\section{2. Объекты, которые можно микроскопировать только по-} сле предварительного препарирования или хирургического вмешательства и заключения в искусственную среду.

К этой категории объектов относятся клетки и ткани наземных растений, но не любые, а только наименее повреждаемые, т.е. те, которые можно легко отделить от растения. Для препарирования таких объектов используют три метода: изолирование отдельных клеток и тканей, изготовление срезов через ткани, инфильтрирование тканей.

\section{Среды для прижизненных наблюдений}

Вопрос о среде для прижизненных наблюдений растительных клеток является одним из важнейших: среда должна быть безвредной. Лучше всего использовать прудовую или водопроводную воду, выдержанную в открытой посуде в течение 6- 12 ч для обесхлоривания. Эти жидкости представляют собой растворы, физиологически уравновешенные в отношении солей, их реакция близка к нейтральной, что благоприятно для большинства объектов. Для уравновешивания осмотического давления клеток и среды, в которую они погружены, к воде рекомендуется добавить небольшое количество сахарозы (от 0,5 до $3 \%$ ).

Дистиллированную воду применять не следует, так как она обладает очень высокой кислотностью $(\mathrm{pH} 5-5,5)$ и физиологически не уравновешена (в ней нет растворенных солей, как в водопроводной или прудовой воде). Благодаря содержанию следов меди и других металлов, часто появляющихся в дистиллированной воде при перегонке, она легко вызывает повреждение цитоплазмы. При длительном действии дистиллированная вода является сильным ядом для живых растительных клеток.

Кратковременные прижизненные наблюдения можно проводить в индифферентном парафиновом масле, хорошо сохраняющем целостность строения клеток. Однако для более продолжительных по времени исследований парафиновое масло не рекомендуется, так как прекращение доступа кислорода через масло нарушает дыхание. 


\section{Среды, улучшающие микроскопическое изображение жи- вых клеток и тканей}

Эпидерма наземных органов растений, как правило, покрыта слоем кутикулы, которая часто имеет неровный рельеф: с бороздками, складками, шипиками и др. Неровность кутикулы при микроскопировании эпидермы служит препятствием, не позволяющим четко видеть внутриклеточное содержимое. Для устранения этого препятствия необходимо микроскопирование проводить не в воде, показатель преломления которой равен 1,33, а в среде, показатель преломления которой близок к показателю преломления кутикулы. Такая среда, заполняя все неровности поверхности кутикулы, оптически гомогенизирует ее. Чем ближе показатель преломления среды к показателю преломления кутикулы, тем более невидимой становится последняя. Показатель преломления кутикулы составляет 1,47-1,52. Близким показателем преломления обладает вазелиновое масло $(1,48)$, а также целый ряд силиконовых масел, показатель преломления которых лежит в пределах от 1,47 до 1,53. И вазелиновое и силиконовое масла почти не токсичны для растительных клеток; применяя их, можно оптически, а не хирургически устранять мешающие при микроскопировании скульптурные утолщения кутикулы, оболочки и др.

Кусочки органов после инфильтрации их водой обсушивают с поверхности фильтровальной бумагой, помещают в каплю масла, накрывают покровным стеклом и микроскопируют. В эпидермальных клетках хорошо видно внутриклеточное содержимое. При просмотре таких же кусочков в воде виден только рельеф кутикулы, внутреннее содержимое рассмотреть не удается.

\section{Микроскопирование живых объектов}

\section{в течение продолжительного времени}

Прижизненное изучение растительных объектов нередко требует вести наблюдение в течение нескольких часов и даже дней, например наблюдения за прорастанием пыльцевых зерен и ростом пыльцевых трубок у высших растений, прорастанием спор грибов, ростом мицелия и т.д. В этом случае необходимо создать объектам оптимальные для их жизни условия (температура, влажность, аэрация и др.). В таких случаях микроскопирование объекта на предметном стекле под покровным стеклом невозможно и необходимо использовать так называемые влажные камеры. Камера должна по 
своим габаритам допускать использование ее на предметном столике микроскопа и должна позволять вести наблюдения над объектом по возможности со всех сторон.

Учитывая малую величину рабочего расстояния большинства объективов, особенно больших увеличений, желательно, чтобы камера, хотя бы в одном из направлений, имела минимальные размеры. Поэтому при использовании объективов с увеличением выше 20 нужно, чтобы одна из стенок камеры была сделана из покровного стекла. Этому условию наиболее полно отвечают камеры Ранвье и кольца Ван-Тигема,

Для мелких объектов подходят камеры Ранвье - предметные стекла, на которых вышлифованы углубления со сферической поверхностью, накрываемые покровным стеклом. Предварительно предметное стекло на расстоянии около 1 см от краев лунки промазывается вазелином с помощью стерильной стеклянной палочки. На него накладывается второе предметное стекло с лункой, повернутое верхней стороной книзу, так что вазелин распределяется тонким слоем. Подготовленное таким образом предметное стекло накладывается на покровное стекло, на которое предварительно наносится капля жидкости с объектом. После этого стекло переворачивают и покровное стекло окантовывают с помощью кисточки смесью расплавленного парафина с канадским бальзамом (10:1).

Камеры Ранвье отличаются от обычных предметных стекол большей толщиной и наличием на поверхности сферического углубления. В силу этих причин они искажают ход лучей при микроскопировании объекта.

От этого недостатка свободны кольца Ван-Тигема - невысокие стеклянные цилиндрики, изготовленные из стеклянной трубки с наружным диаметром до 1,5 см и толщиной стенок 1,2- 2 мм, оба основания которых - верхнее и нижнее - шлифуются. Кольца легко выдерживают стерилизацию в автоклаве или сушильном шкафу. Они приклеиваются вазелином к предметному стеклу, а покровное стекло, которое служит им крышкой, после нанесения капли влаги на предметное стекло и капли среды с объектом на нижнюю поверхность покровного приклеивается к верхнему основанию кольца подогретым вазелином. Используются камеры для изучения более крупных объектов и для наблюдения за ростом пыльцевых трубок. 
Прозрачность стенок обоих типов влажных камер обеспечивает не только удобство наблюдения, но и возможность культивирования автотрофных организмов при постоянном контроле под микроскопом. Наблюдаемые картины развития можно легко сфотографировать.

\section{Приготовление давленых препаратов}

Давленные препараты могут использоваться при изучении митоза, кариотипов, хромосомных нарушений в корешках и конусах нарастания стеблей; мейоза - в молодых пыльниках различных растений.

Для приготовления давленных препаратов используют фиксатор Карнуа - уксусный алкоголь (6 частей абсолютного спирта +3 части хлороформа +1 часть ледяной уксусной кислоты) или фиксатор Кларка - уксусный алкоголь (3 части абсолютного спирта + 1 часть ледяной уксусной кислоты). Окрашивание препарата можно проводить различными красителями: ацетокармином, ацетоарсеином, ацетолакмоидом, метиленовой синькой.

Чаще используют для окрашивания ацетокармин, приготовленный следующим образом. 1 г кармина растворяют в 45 мл ледяной уксусной кислоты и 55 мл дистиллированной воды. Растворение ведется в колбе с обратным холодильником на водяной бане в течение 30-60 минут. После остывания раствор кармина фильтруют и помещают в посуду с притертой пробкой.

В настоящее время разработаны ускоренные методики в микроскопической технике. Так, приготовление давленных препаратов не требует той сложной обработки материала, которая обязательна при приготовлении постоянных микротомных препаратов.

Метод 1 - изолирование отдельных клеток и тканей. Наиболее доступны для изолирования без повреждений живые клетки мякоти сочных плодов, при созревании которых происходит естественный (ферментативный) процесс мацерации мягких тканей перикарпия. Клетки легко извлекают с помощью препаровальной иглы или пинцета, помещают в каплю воды на предметное стекло и накрывают покровным стеклом. Чтобы не повредить и не раздавить нежные клетки, под покровное стекло подкладывают осколки покровного стекла или кусочки фильтровальной бумаги.

Удобным объектом могут служить волоски на надземных органах растения (листья, стебли, лепестки, тычиночные нити), а также корневые волоски. Их отделяют с помощью острой бритвы вместе 
с кусочком поверхностной ткани органа (эпидермы или эпиблемы). Классическим объектом считаются волоски тычиночных нитей из бутонов традесканции виргинской. Для препарирования выбирают бутон длиной 3-4 мм и срезают основание бритвой так, чтобы можно было все органы бутона легко препарировать по отдельности. Тычиночные нити после осторожного отделения пыльников помещают в водопроводную воду, к которой добавляют каплю раствора сахарозы (или в парафиновое масло), и накрывают покровным стеклом с подпорками. Волоски тычиночных нитей состоят из бочонкообразных клеток, прижизненное микроскопирование которых позволяет наблюдать струйчатое движение цитоплазмы, митотическое деление и др. Корневые волоски в любое время можно получить от проростков злаков (пшеница, рожь, овес, ячмень и др.), проращивая зерновки в чашках Петри на влажной фильтровальной бумаге.

В качестве примера изолирования тканей для прижизненного исследования может служить верхняя (внутренняя) эпидерма чешуи луковицы репчатого лука. Используют только луковицы, находящиеся в состоянии покоя. Верхняя эпидерма живых внутренних чешуи луковицы имеет очень слабую связь с мезофиллом, поэтому ее легко отделить без сколько-нибудь значительных повреждений. Из луковицы вырезают сектор, отдельные части (чешуи) которого без затруднения отделяются друг от друга. Физиологически чешуи луковицы неравноценны: внутренние самые молодые, наружные самые старые. Целесообразно выбрать чешую из средней зоны, а в экспериментах, где необходимо обеспечить сравнимость опыта и контроля, нужно всегда брать кусочки эпидермы с одной и той же чешуи. На вогнутой поверхности чешуи острым лезвием безопасной бритвы делают квадратные надрезы со стороной не более 5 мм, не слишком глубокие, чтобы не прорезать чешую насквозь. После этого с каждого квадратика с помощью тонкого пинцета легко захватить за край и снять плёночку эпидермы. Ее немедленно переносят в каплю воды на предметное стекло нижней стороной к воде. Эпидерму можно снять с чешуи целиком, не делая надрезов, но при этом неизбежно происходит ее натяжение, приводящее к повреждению клеток. Небольшое повреждение клеток, проявляющееся в снижении структурированности ядер и остановке движения цитоплазмы, имеет место и при снятии небольших пленок. Эти повреждения носят обратимый характер. Чтобы их устранить, необходимо до микроскопирования выдержать снятые 
плёночки эпидермы на поверхности обесхлоренной водопроводной воды в течение 2- 3 ч. За это время в клетках восстанавливается движение цитоплазмы и структура ядра. Чтобы свести к минимуму повреждения при снятии эпидермы, чешую луковицы можно предварительно ин-фильтровать водой. Благодаря массирующему действию пузырьков воздуха связь эпидермы с мезофиллом сильно ослабляется и отдельные квадратные участки особенно легко снимаются. Для инфильтрации используют вакуум-эксикатор, соединенный с насосом, или обыкновенный медицинский шприц.

Применяется шприц емкостью 10 или $20 \mathrm{~cm}^{3}$. Из него вынимают поршень, прикрывают пальцем отверстие наконечника и наливают немного инфильтруемой жидкости с кусочками тканей. Затем вставляют поршень, переворачивают шприц наконечником вверх и вдвигают поршень до тех пор, пока весь воздух не выйдет из шприца через отверстие наконечника. После этого вновь закрывают отверстие наконечника и, прилагая некоторое усилие, отводят поршень назад вниз. Над жидкостью создается вакуум, и из нее и кусочков начинают быстро выделяться пузырьки. Степень вакуума и скорость его образования можно легко регулировать по желанию. Через минуту поршень постепенно или сразу отпускают, вакуум ликвидируется, и в межклетники устремляется окружающая жидкость. Повторяя оттяжку поршня 2- 3 раза, удается получить хорошую инфильтрацию ткани.

Метод 2 - изготовление срезов через ткани. Если изолировать клетки, не повреждая, нельзя, то из ткани делают срезы. При изготовлении среза клетки неизбежно повреждаются и отмирают. Поэтому, чтобы в срезе сохранилась хотя бы часть живых клеток, для прижизненных наблюдений необходимо делать толстые срезы так, чтобы в их средней части сохранилось 2- 3 слоя неповрежденных клеток. Последние, однако, всегда испытывают раневое раздражение. Чтобы уменьшить его, необходимо пользоваться острой бритвой и делать срез по возможности без надавливания, скользящим движением, смачивая бритву и срез водой.

Из таких органов растения, как листья, для прижизненных наблюдений лучше делать не срезы, а высечки, так как в высечках ткани повреждаются гораздо меньше. Их можно делать с помощью пробочного сверла или острого лезвия бритвы, положив лист на смоченную водой корковую пробку или сложенную в несколько слоев фильтровальную бумагу. 
Вследствие большого содержания воздуха в межклетниках растительных тканей просматривать под микроскопом срезы или высечки невозможно, так как они непрозрачны из-за рассеивания света пузырьками воздуха. Чтобы устранить эту помеху, необходимо удалить воздух из межклетников и заместить его водой или другой жидкой средой, т.е. инфильтровать ткань. После этой операции кусочки ткани становятся прозрачными и при микроскопировании можно наблюдать отдельные клетки и их содержимое.

Метод 3 - инфильтрация тканей. Во избежание повреждения клеток и тканей при их отделении от растения прибегают к микроскопированию целых частей растения, так что исследуемые ткани сохраняют естественное положение в органе. Этот метод применим только для прижизненного исследования тонких объектов, таких, например, как лепестки и листья, и в качестве обязательного условия требует предварительной инфильтрации объекта любым из вышеназванных способов.

Если два предыдущих метода используются в основном в цитологических и цитофизиологических исследованиях, то метод инфильтрации тканей - преимущественно в анатомии и клеточной физиологии растений.

Методы инфильтрации имеют значение не только для подготовки объекта к микроскопированию; с их помощью можно вводить внутрь тканей желаемые вещества, не повреждая самих тканей.

Приготовьте давленный препарат по следующей методике:

1. Фиксация в уксусном алкоголе.

2. Промывка материала в 70\%-ном спирте до исчезновения запаха уксусной кислоты.

3. Хранение материала в 70\%-ном спирте.

4. Промывка материала в воде.

5. Материал помещают в краситель на 3-5 минут и подогревают на спиртовке (объект доводят до кипения).

6. Окрашенный объект кладут на предметное стекло в каплю 45\%-ной уксусной кислоты или раствора хлоралгидрата, покрывают покровным стеклом и фильтровальной бумагой, постукивают сверху спичкой или слегка раздавливают пальцем до образования мазка.

7. Готовые препараты можно окантовать парафином, лаком (для их более длительного использования). 


\section{Вопросы для обсуждения:}

1. Какие объекты можно микроскопировать без предварительного препарирования?

2. Какие объекты требуют обязательного препарирования перед микроскопированием?

3. Каковы особенности сред для прижизненных наблюдений?

4. Какие среды улучшают микроскопическое изображение клеток и тканей?

5. Каковы методы изготовления давленых препаратов? 


\section{ЛАБОРАТОРНАЯ РАБОТА № 3}

Тема: «Прижизненное окрашивание»

Цель: освоить технику прижизненного окрашивания препаратов.

\section{Оборудование, материалы, реактивы:}

1. Микроскоп

2. Растворы красителей: метиленовый синий, раствор Люголя

3. Предметные и покровные стекла

4. Тигли фарфоровые

5. Лук репчатый

\section{Самостоятельная работа студентов}

1. Ознакомиться с основными витальными красителями.

2. Приготовить и окрасить временные препараты эпидермы чешуи и корешка лука раствором Люголя, метиленовым синим, метиленовым оранжевым, янусом зеленым.

Метод прижизненного окрашивания используют для исследования с 90-х гг. XIX в. Однако и в современной цитологии этот способ продолжает играть важную роль. Он позволяет изучать микроскопическое строение клеток, химические процессы, происходящие в них, а также физико-химические свойства цитоплазмы. Именно прижизненное окрашивание клеток и тканей в ряде случаев обеспечивает одновременное исследование особенностей их строения и функционирования. Отношение клеток к прижизненным красителям, являясь одним из критериев их физиологического состояния и уровня жизнедеятельности, позволяет выявить ранние функциональные изменения, неуловимые с помощью других методических приемов, что выходит за рамки цитоморфологии и представляет собой один из основных методов цитофизиологии. Широкое применение этого метода оправдано относительной простотой приемов, высокой чувствительностью и возможностью в короткий срок получать закономерно повторяющиеся результаты.

Среди большого числа цитологических красителей лишь некоторые способны вызывать окрашивание живой клетки. Такие красители называются витальными. Они должны удовлетворять по крайней мере двум требованиям: обладать минимальной токсичностью для структур клетки и способностью проникать в клетку и ее структуры через оболочку и цитоплазматические мембраны.

Другие витальные красители окрашивают только мертвые клетки 
и, следовательно, могут быть использованы для быстрого определения жизнеспособности клеток в культуре клеток и в тканях.

Наименьшее отрицательное влияние на процессы жизнедеятельности клеток оказывают слабые водные растворы красителей. Нейтральный красный, метиленовый синий, янус зеленый и т.д. составляют восходящий ряд витальных красителей по степени их токсичности. Естественно, что чем мельче частицы, тем скорее и в большем количестве они могут поступать в клетку. Поскольку размеры частиц ряда красителей зависят от степени их разведения, то лучшие результаты окрашивания получаются при более низких концентрациях красителя. Для растительных объектов наиболее часто используются концентрации красителей порядка 1:10000 и менее. Красители, обладающие повышенной токсичностью, например янус зеленый, разводят еще сильнее, применяя растворы 1:20000 и 1:50000.

Из этих двух требований, предъявляемых к витальным красителям, вытекают и некоторые общие правила работы с ними:

- необходимо использовать только свежеприготовленные растворы красителей;

- красители готовят на водопроводной воде;

- такая вода служит наиболее подходящей средой для наблюдения живых клеток; на дистиллированной воде можно приготовить растворы более высоких концентраций (1:1000, 1:500), а перед употреблением разбавить водопроводной водой;

- буферные растворы красителя пригодны для работы лишь в течение суток;

- концентрацию растворов красителей необходимо подбирать в зависимости от объекта, длительности эксперимента и свойств применяемого красителя (токсичность, растворимость и др.);

- важным условием успешного окрашивания является хорошая аэрация клетки.

При изучении прижизненно окрашенных клеток существенным моментом является наличие критериев, подтверждающих, что клетки живы и в их физиологическом состоянии не произошло патологических изменений. Хорошими критериями служат активное движение цитоплазмы, хорошо заметное по перемещению митохондрий, пластид и включений, а также способность клеток к плазмолизу. 
Прижизненное окрашивание применяется для решения следующих задач:

1) для выявления внутриклеточных структур (например, прижизненное окрашивание янусом зеленым позволяет идентифицировать митохондрии с помощью светового микроскопа);

2) для изучения закономерностей поступления веществ в клетку, их накопления и выделения, а также характера перемещения продуктов обмена между тканями (применяемые красители служат экспериментатору в качестве модельных веществ с заведомо известными физико-химическими свойствами);

3) для дифференциации морфологически однородных, но функционально различающихся клеток (объектами могут быть, например, клетки нектарников в цветках; морфологически они неразличимы, но при витальном окрашивании клетки, вырабатывающие нектар, сразу выделяются интенсивной окраской; отражением функциональных различий служит также избирательное окрашивание замыкающих клеток устьиц, железистых волосков и др.);

4) для определения физиологического состояния клеток в культуре клеток и в тканях, например живые клетки или мертвые;

5) для определения $\mathrm{pH}$ внутриклеточных структур;

6) для исследования проницаемости цитоплазмы;

7) для выявления изменений, происходящих в клетках под влиянием различных повреждающих агентов (экспериментальных или факторов внешней среды) и патологических процессов. Изменение характера прижизненной окраски используется для выявления субстанциональных изменений клеток и тканей.

\section{Красители и их свойства}

Витальные красители представляют собой органические соединения ароматического ряда. Окраска их зависит от определенных групп, называемых хромофорными. По оптическим свойствам все используемые красители можно разделить на две группы: красители для видимого света и флуоресцентные красители, или флуорохромы. Наблюдения клеток, окрашенных флуорохромами, производят с помощью флуоресцентного микроскопа.

Большинство витальных красителей в водных растворах диссоциировано и представляет собой, таким образом, электролиты. По химическим свойствам витальные красители делят на основные, кислотные и электронейтральные. 
Основные, или катодные, красители. У основных красителей хромофорная группа находится при катионе. Когда краситель в растворе диссоциирован, окрашивающей частью раствора являются катионы. Так как при действии электрического тока такие красители накапливаются на катоде, то их называют также катодными красителями. Их диссоциация сильно зависит от значения $\mathrm{pH}$ раствора. Основные красители максимально диссоциированы в кислых растворах. При постепенном повышении значения $\mathrm{pH}$ раствора диссоциация красителя понижается. При щелочной реакции в растворе остаются недиссоциированные молекулы соли красителя или основания красителя. Для каждого основного красителя существует область $\mathrm{pH}$, при которой его диссоциация практически равна нулю и краситель существует в виде недиссоциированных молекул. Многие основные красители при переходе в эту область $\mathrm{pH}$ изменяют свою окраску, катионы в таком случае окрашены иначе, чем недиссоциированные молекулы красителя. Такие красители называют индикаторами. Они могут быть одноцветными (когда одна модификация - ионы или молекулы - бесцветна, а другая окрашена) или двуцветными (когда обе модификации имеют резко различную окраску). Из основных красителей наиболее часто употребляют нейтральный красный, метиле-новый синий, толуидиновый синий и янус зеленый.

Кислотные, или анодные, красители. Они представляют собой соли красителей-кислот. Их хромофорная группа находится при анионе. Так как при действии электрического тока они накапливаются на аноде, их называют также анодными. Кислотные красители обнаруживают обратное по сравнению с основными красителями отношение между диссоциацией и значением $\mathrm{pH}$. В кислых растворах они существуют в виде недиссоциированной кислоты или в виде молекул соли. При изменении реакции среды в щелочную сторону диссоциация увеличивается, и при щелочных значениях рН она достигает своего максимума. Среди этой группы красителей также имеются одноцветные и двуцветные индикаторы. Из кислотных красителей наиболее часто употребляются индигокармин, кислый фуксин, эозин и др.

Можно с помощью простого опыта определить, с какого рода красителем мы имеем дело. Для этого на полоску фильтровальной бумаги наносят каплю раствора испытуемого красителя. Если в течение первых секунд краситель и вода распространяются по бумаге 
с одинаковой скоростью, то перед нами кислотный краситель, так как отрицательно заряженная бумага не может электростатически задержать ионы красителя, также имеющие отрицательный заряд. Если же в течение первых секунд капиллярного распространения происходит ясное разделение воды и красителя, так что последний задерживается, перед нами основной краситель.

Электронейтральные красители. Некоторые основные и кислотные красители даже в оптимальных областях $\mathrm{pH}$ диссоциированы так слабо, что обнаружить у них действие ионов практически невозможно. Такие красители не могут накапливаться электроадсорбционным путем, поэтому их можно назвать электронейтральными. При любом значении рН их окрашивающая способность остается постоянной. Пример - родамин В.

При витальном окрашивании растительных клеток основными красителями в близкой к нейтральной среде (рH 6-8) краситель накапливается в вакуоли, а цитоплазма и ядро остаются неокрашенными. У большинства растительных клеток содержимое вакуолей окрашивается равномерно (диффузное окрашивание), но у некоторых растений краситель в вакуолях может отмешиваться в виде коацерватных капель (капельное окрашивание) или зернистых скоплений (зернистое окрашивание).

Кислотные красители почти не окрашивают или очень слабо окрашивают живые клетки. Мертвые клетки окрашиваются гораздо интенсивнее, чем живые. На этом основано выявление жизнеспособных семян и определение их всхожести индигокармином и кислым фуксином, а также определение процента поврежденных или мертвых клеток в культуре клеток и в тканях.

\section{Техника прижизненного окрашивания}

Приготовите и окрасьте временные препараты эпидермы чешуи и корешка лука раствором Люголя, метиленовым синим, метиленовым оранжевым, янусом зеленым.

Окрашивание проводится путем погружения объекта в раствор красителя, который наливают в часовое стекло или фарфоровый тигелек. В случае необходимости предварительно удаляют воздух из межклетников при помощи вакуумного аппарата.

Если наблюдения кратковременные, объект можно изучать в капле красителя, в которой производилось окрашивание. Во всех иных случаях по окончании окрашивания материал быстро промывают водопроводной водой и в ней производят наблюдения. 
Закрыть покровным стеклом объект нужно непосредственно перед микроскопированием, чтобы он не находился лишнее время в условиях кислородного дефицита.

Для разных красителей и объектов время пребывания в растворе сильно варьирует. Обычно окрашивание продолжается 10-20 мин, после чего наблюдения могут проводиться в течение 3-10 мин. Быстро окрашивающиеся объекты, например пыльцевые зерна, достаточно выдерживать в растворе красителя 3-8 мин.

\section{Вопросы для обсуждения:}

1. Для чего используют прижизненное окрашивание?

2. Какие требования предъявляются к витальным красителям?

3. Какие красители относятся к основным? К кислотным?

4. Приведите примеры электронейтральных красителей.

5. Опишите технику прижизненного окрашивания. 


\title{
ЛАБОРАТОРНАЯ РАБОТА № 4
}

\author{
Тема: «Типы фиксаторов, их состав, \\ механизм действия и использование»
}

Цель: получить навыки по приготовлению фиксаторов и спиртов заданной концентрации.

\section{Посуда, материалы, реактивы:}

1. Спирт этиловый $96 \%$

2. Глицерин

3. Вода дист.

4. Сульфат меди $\mathrm{CuSO} 4 \cdot 5 \mathrm{H}_{2} \mathrm{O}$ (насыщенный раствор)

5. Формалин $40 \%$

6. Пенициллиновые пузырьки с пробкой

7. Вата

8. Марля

9. Пипетки на 1 мл, на 10 мл

10. Груши резиновые

11. Палочки стеклянные

12. Стаканы на 50 мл

\section{Самостоятельная работа студентов}

1. Ознакомиться с процедурой фиксации, типами фиксаторов.

2. Приготовить фиксатор Гаммалунда и копенгагенскую смесь и зафиксировать корни чеснока и листья.

3. Приготовить спирты заданной концентрации.

\section{Подбор объектов для исследования}

Для цитологических и эмбриологических исследований важно определить, какие органы и ткани растения необходимы для работы. При изучении митоза используют меристему молодых корней, конусы нарастания стеблей, молодые листья. Для изучения мейоза и подсчета числа хромосом во время деления материнских клеток микроспор используют у злаковых растений молодые колосья, у других растений небольшие бутоны, иногда молодые пыльники. Оплодотворение и различные этапы эмбриогенеза наблюдают в опыленных цветках через определенные промежутки времени после нанесения пыльцы на рыльце.

\section{Предобработка материала перед фиксацией}

Наиболее часто для предобработки используются следующие вещества: колхицин, парадихлорбензол, монобромнафталин, 8-оксихинолин и др. 
1. Колхицин - объекты подвергают обработке в водных растворах колхицина с концентрацией $0,2-0,5 \%$ в течение $1-2$ часов при комнатной температуре.

2. Парадихлорбензол - предобработку проводят в насыщенном водном растворе при температуре $12-16^{\circ} \mathrm{C}$ в течение $2,5-3$ часов. Парадихлорбензол плохо растворяется в воде, поэтому раствор необходимо периодически взбалтывать в закрытой посуде (5-10 г парадихлорбензола растворяют в 500 мл воды и выдерживают бутыль в течение ночи в термостате при температуре около $60^{\circ} \mathrm{C}$ ).

3. 8-оксихинолин - объекты подвергают обработке в 0,002-молярном растворе 8 -оксихинолина $(0,058$ г в 200 мл воды) в течение 3-х часов при температуре $12-16^{\circ} \mathrm{C}$.

Можно проводить предобработку холодом. Объекты (отрезанные корни или листья) помещают в сосуды с предварительно охлажденной водой и выдерживают в холодильнике при температуре 0$2{ }^{\circ} \mathrm{C}$ в течение 24 часов.

После предобработки объекты тщательно промывают.

\section{Типы фиксаторов, их состав, механизм действия и исполь- зование}

Фиксация - это обработка материала, при котором быстро прерываются жизненные процессы в объекте и сохраняются по возможности неизменными тонкие структуры клеток и тканей. В результате фиксации клеточные коллоиды, способные набухать и изменять свою форму, превращаются в стойкие неэластичные гели. Основная цель фиксации - сохранить объект в таком состоянии, какое он имеет в живом органе. Изменения, вызванные фиксацией, необратимы.

Фиксатор должен оказывать:

1) свертывающее действие, то есть вызывать коагуляцию содержимого клетки;

2) уплотняющее действие, а именно закрепить ткань, перевести компоненты клеток в нерастворимое состояние, чтобы структура клеток стала устойчивой для дальнейшей обработки;

3) химическое воздействие (чтобы объект мог воспринимать краску), а также производить оптическую дифференцировку содержимого. 


\section{Классификация фиксаторов}

Идеальных фиксаторов - таких, которые бы в точности сохраняли микроскопические структуры взятых для фиксации тканей, не существует. Один и тот же фиксатор не одинаково хорошо фиксирует различные ткани, по-разному выявляет различие их структур. Поэтому фиксатор выбирают с учетом особенностей материала, взятого для микроскопического исследования. Кроме того, способ фиксации значительно ограничивает возможность применения тех или иных методов окраски при дальнейшей обработке материала.

В зависимости от характера действия фиксаторы делят на следующие группы:

1) фиксирующие ядро, или ядерные фиксаторы (фиксаторы Навашина, Модилевского, Карнуа, Яковлева и др.);

2) фиксирующие цитоплазму (фиксаторы Флемминга, Германа и др.);

3) фиксирующие митохондрии и пластиды (фиксаторы Левитского, Рего, смесь Гаммалунда и др.);

4) фиксаторы для цитохимических исследований (фиксаторы Бродского - ФСТ; Бирх-Гиршфельда, Карнуа и др.).

При цитологических и эмбриологических исследованиях чаще всего используют ядерные фиксаторы. В состав ядерных фиксаторов могут входить ледяная уксусная кислота, формалин, хлороформ, осмиевая кислота, спирт и др.

Обычно фиксатор представляет смесь нескольких реактивов. Один реактив редко используется для фиксации вследствие одностороннего действия.

В зависимости от растворителя фиксаторы делят на

1) водные (например, фиксаторы Навашина и Модилевского),

2) спиртовые (например, раствор Карнуа и Чемберлена).

Водные фиксаторы медленно проникают в клетки растений, поэтому в них материал выдерживают от 24 часов до нескольких суток. В спиртовых - материал фиксируется быстрее, поэтому время их воздействия может составлять от 30 минут до 12 часов в зависимости от размеров материала. Фиксация спиртовыми фиксаторами более грубая, поэтому для небольших нежных объектов предпочтительнее водные фиксаторы. Для крупных объектов водные фиксаторы непригодны, так как плохо проникают в них. 


\section{Состав наиболее распространенных фиксаторов:}

1. Фиксатор Навашина (10:4:1): 10 частей 1\% раствора хромовой кислоты, 4 части 16\% раствора формалина (или 40\% раствора от продажного), 1 часть ледяной уксусной кислоты. Смешивать растворы можно только непосредственно перед фиксацией, так как фиксирующая смесь быстро портится (формалин окисляется хромовой кислотой). Фиксатор Навашина действует очень мягко, хорошо сохраняет структуру хромосом, продолжительность фиксации - 24 часа в темноте.

2.Фиксатор Модилевского (9:2:2:2): 9 частей $1 \%$ раствора хромовой кислоты, 2 части $16 \%$ раствора формалина, 2 части 5\% раствора двухромо-вокислого калия, 2 части 5\% раствора уксусной кислоты. По действию на материал сходен с фиксатором Навашина. Время фиксации 24 часа.

3. Фиксатор Карнуа (6:3:1): 6 частей 100\% или 96\% этилового спирта, 3 части хлороформа, 1 часть ледяной уксусной кислоты. Продолжительность фиксации от 2 до 12 часов. Приготовленный фиксатор можно хранить до одной недели, но лучше готовить перед употреблением.

4. «Уксусный алкоголь» (3:1): 3 части 100\% или 96\% этилового спирта, 1 часть ледяной уксусной кислоты. Продолжительность фиксации от 2 до 12 часов.

5. Фиксатор Чемберлена (90:5:5) или (18:1:1): 90 частей 50-70\% этилового спирта, 5 частей 40\% формалина (продажного), 5 частей ледяной уксусной кислоты. Продолжительность фиксации 12-16 часов, но при необходимости в этом фиксаторе материал можно хранить более продолжительное время. По характеру действия фиксатор Чемберлена занимает промежуточное положение в сравнении с фиксаторами Карнуа и Навашина.

6. Фиксатор Ньюкомера (6:3:1:1:1): 6 частей изопропилового спирта, 3 части пропионовой кислоты 1 часть петролейного эфира, 1 часть ацетона, 1 часть диоксана. Материал в фиксаторе выдерживают в течение 24 часов при комнатной температуре, затем заливают свежим раствором фиксатора и хранят в холодильнике. Фиксатор дает очень хорошие результаты, особенно при фиксации мейоза, его можно готовить заранее. Однако следует помнить, что диоксан и пропионовая кислота - сильные яды, работать с этим фиксатором можно только в резиновых перчатках и под тягой. Перед исследованием объекты трижды промывают в 96\% спирте. 


\section{Правила фиксации}

Выбор фиксатора должен отвечать целям исследования и зависеть от объекта.

Объем фиксирующей жидкости должен в несколько раз (обычно не менее, чем в 50 раз) превышать объем фиксируемого материала. Для фиксации корней удобно использовать плоскодонные пробирки диаметром 1,5-2 см и полезным объемом не менее 7-10 мл.

Фиксировать совершенно свежий материал лучше на месте его произрастания. Если это по какой-либо причине невозможно сделать, то материал собирают большими частями. Например, в виде веток с бутонами иди цветками. Привезенный материал на некоторое время помещают в воду, чтобы все части растения приняли нормальный вид; лишь после этого приступают к его обработке.

Корешки брать только прямые, длиной 7-8 мм. При фиксации эмбриологического материала удаляют ненужные части (лепестки, чашелистики, цветоножки и др.).

Для лучшего и равномерного пропитывания материала фиксатором стараются брать небольшие кусочки ткани. Крупные объекты перед фиксацией разрезают на несколько частей (например, корзинки сложноцветных). Бутоны фиксируют целиком, а колосья желательно предварительно разобрать на колоски. Если проникновение фиксатора будет неполным, то такой материал в дальнейшем даст неправильную картину и приведет к неправильным выводам.

Для лучшего проникновения фиксатора в ткани поступают следующим образом:

a) на дно сосуда, в котором проводится фиксация, помещают кусочки ваты с тем, чтобы фиксируемый материал не прилегал непосредственно ко дну сосуда;

б) если кусочки не опускаются на дно, а плавают по поверхности жидкости, это значит, что проникновению фиксатора мешает воздух, находящийся в растительных тканях. Наиболее просто можно удалить воздух энергичным и продолжительным встряхиванием склянки с фиксирующей жидкостью и помещенной в нее тканью или накрыванием объекта кусочком ваты, который, намокая в жидкости, увлекает его на дно сосуда.

Время фиксации в течение суток следует определять для каждого конкретного случая. Корни фиксируют в те часы, когда наблюдается максимальное число митозов. При изучении процесса оплодотворения и развития зародыша эмбриологические объекты 
фиксируют через определенные промежутки времени после нанесения пыльцы на рыльца.

Следует соблюдать время, рекомендуемое для фиксации. Длительное пребывание материала в большинстве фиксаторов значительно ухудшает результаты последующей обработки.

Фиксирующие растворы следует готовить непосредственно перед употреблением. Повторное использование фиксатора, уже бывшего в употреблении, нежелательно.

\section{Промывка материала от фиксатора и его обезвоживание}

После фиксации материал необходимо тщательно промыть для удаления остатков фиксирующего вещества или продуктов их разложения. Если вовремя этого не сделать, то могут произойти нежелательные изменения тканей (чрезмерное уплотнение, или хрупкость, или, наоборот, мацерация).

При использовании водных или спиртовых фиксаторов промывку ведут неодинаково. Промывка ведется спиртом в том случае, если использовался спиртовой фиксатор, и водой - при применении водного фиксатора. Длительность промывки зависит от плотности и размеров фиксируемого материала, она продолжается от 1 часа до суток.

После спиртовых фиксаторов материал рекомендуется промывать три раза по 1-2 часа в $80 \%$ спирте до полного исчезновения запаха уксусной кислоты. Практически это можно осуществить следующим образом. Бюкс с материалом накрывают кусочком марли и осторожно сливают фиксатор, не допуская подсыхания материала. Затем наливают первую порцию $80 \%$ спирта, а спустя указанное время - вторую и третью. Промытый материал можно оставить на хранение в 80 или 70\% спирте.

Если же материал после промывки сразу подвергается дальнейшей обработке, то его лучше промывать не $80 \%$, а $96 \%$ спиртом, это ускоряет процесс обезвоживания. Спирт наливают с таким расчетом, чтобы уровень был на 1-2 см выше объекта.

После использования водных фиксаторов материал промывают в проточной воде в течение 1-24 часов. Продолжительность промывки зависит от температуры. Например, промывка корешков, зафиксированных смесью Навашина, в летнее время составляет 1-2 часа, а зимой 3-4 часа. 
Промывку фиксированного материала удобно проводить или в марлевых мешочках, или цилиндрах, затянутых сеткой. Если отсутствует возможность проводить промывку в проточной воде, то это можно сделать и в бюксах. В этом случае корни промывают в 3-5 сменах водопроводной воды, выдерживая в каждой из них 1015 минут (корни необходимо периодически встряхивать). Затем их промывают в дистиллированной воде. После окончания промывки материала в воде его необходимо частично обезводить в этиловом спирте. Чтобы избежать сморщивания материала, обезвоживание проводят постепенно, используя для этого серию спиртов возрастающей концентрации $(20,40,60$ и 80\%). Их приливают в бюкс и в каждом из них материал выдерживают по 30 минут. В $80 \%$ спирте материал можно хранить длительное время.

Спирт с заданной концентрацией можно приготовить путем разбавления 96\%-ного спирта дистиллированной водой или из двух спиртов с различной концентрацией.

\section{Приготовление фиксатора Гаммалунда и копенгагенской смеси \\ Фиксатор Гаммалунда:}

- концентрированный медный купорос - 15 мл;

- формалин - 1 мл;

- вода - 5 мл.

\section{Копенгагенская смесь:}

- спирт 96\%-й - 13 мл;

- глицерин - 0,5 мл;

- вода - 5 мл.

\section{Разведение спиртов}

Необходимо приготовить спирты заданной концентрации $(20 \%, 40 \%, 60 \%, 80 \%)$ по 50 мл.

Формула разведения этилового спирта:

$$
\mathbf{X}=\mathbf{Y} * \mathbf{B} / \mathbf{A}
$$

Где:

$\mathrm{X}$ - количество исходного этанола, мл;

Y - количество этанола необходимой концентрации, мл;

А - концентрация исходного этанола, \%;

В - необходимая концентрация этанола, \%. 
Для разведения этилового спирта рассчитанное количество этанола помещают в мерную посуду и доливают водой до нужного объема.

Например, необходимо приготовить 100 мл 40\% этилового спирта:

$\mathrm{X}=100$ мл $* 40 \% / 96 \%=41,7$ мл.

41,7 мл 96\% этанола поместить в мерную колбу на 100 мл, довести водой до метки, перемешать.

\section{Вопросы для обсуждения:}

1. Для чего проводится фиксация

2. Как предобрабатывают материалы перед фиксацией?

3. Каков механизм действия фиксаторов?

4. Классификация фиксаторов.

5. Каковы правила фиксации?

6. Как промывают материал от фиксатора?

7. Как проводится обезвоживание? 


\section{ЛАБОРАТОРНАЯ РАБОТА № 5}

\section{Тема: «Методика приготовления постоянных микротомных препаратов».}

Цель занятия: получить навыки по приготовлению постоянных препаратов.

\section{Материаль, оборудование, реактивы}

1. Микротом

2. Для фиксации: фиксатор, мерные цилиндры, бюксы, проросшие семена или луковицы лука, листья, стебли, этикетки.

3. Для приготовления блоков: подставки для блоков, парафиновые палочки, спиртовки, ванночки с водой, заливки (корешки в парафине), препаровальные иглы.

4. Для приготовления срезов: микротомы, чашки Петри с черной бумагой, кисточки.

5. Для расправления срезов на стекле: предметные стекла, трафареты для укладки ленты на предметное стекло, капельницы с водой.

6. Спирт этиловый.

Самостоятельная работа студентов

1. Произвести фиксацию отрезка стебля, листа, корня.

2. Приготовить парафиновые блоки.

3. Приготовить микротомные срезы.

4. Приготовить постоянные препараты.

Для микротомных препаратов готовятся срезы с помощью микротомов. На рисунке 1 представлены: ротационный и салазочный микротом. 


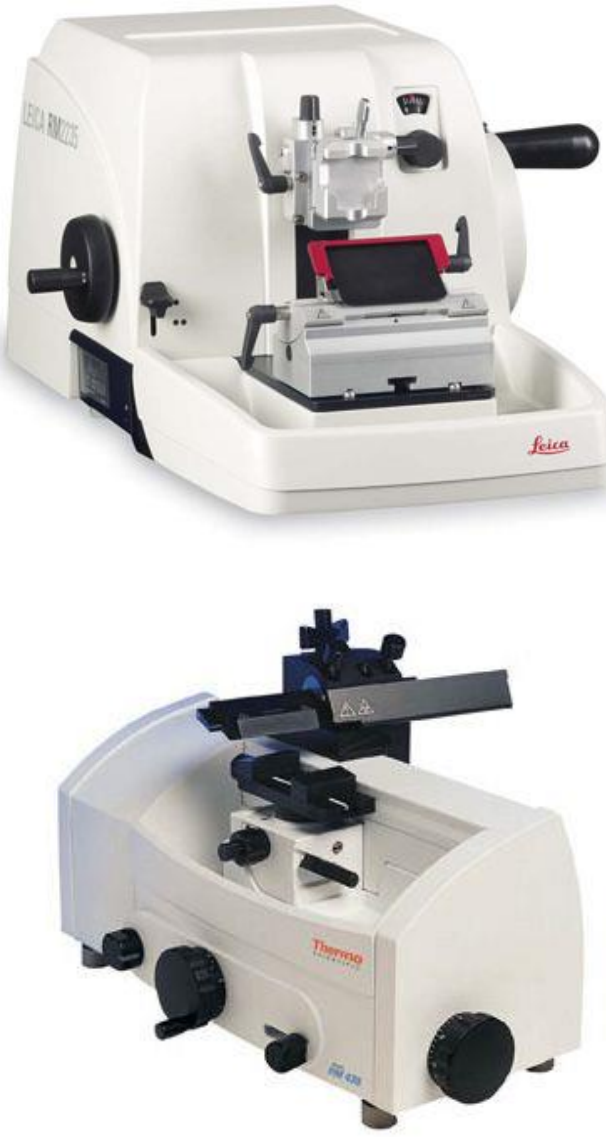

Рис. 1. Микротомы: слева - ротационный; справа - салазочный.

Постоянные микротомные препараты могут долго храниться, не изменяясь. Использование для препаратов микротомных срезов толщиной 10 -20 мкм позволяет изучить митоз, мейоз, микро-, макроспорогенез, процесс оплодотворения и т.д. 


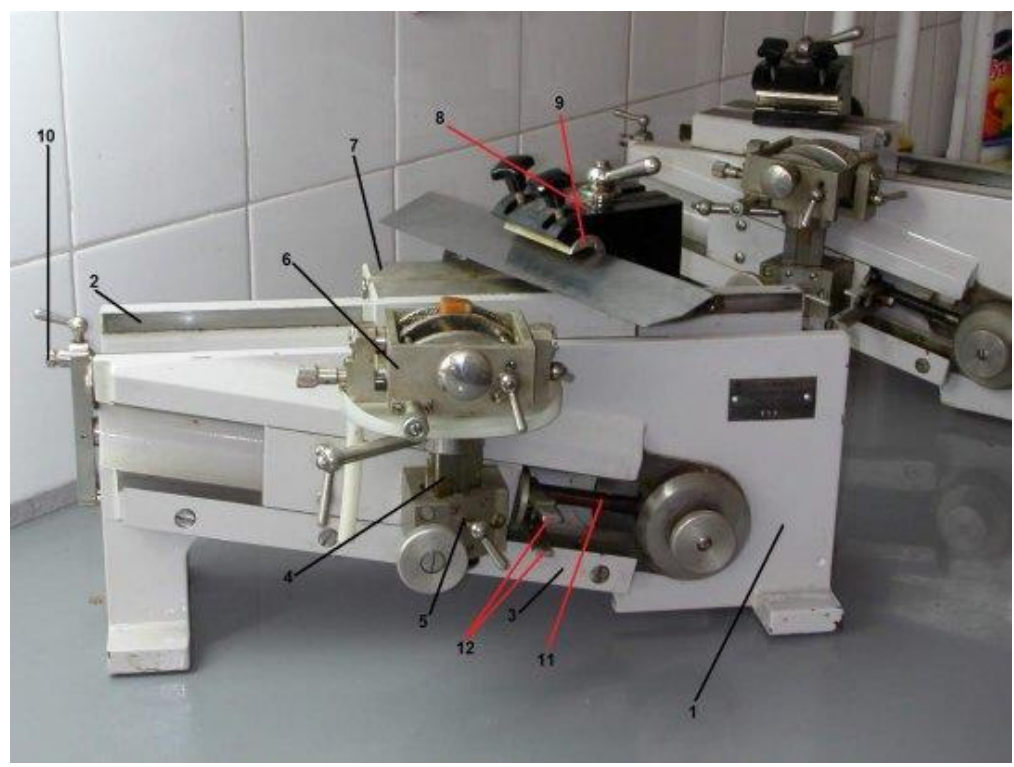

Рис. 2. Устройство салазочного микротома:

1 - станина, 2 - ножедержатель, 3 - направляющие, 4-5 - механизм подъема, 6 - зажим для блока, 7 - ножевые салазки, 8 - ножедержатель, 9 - втулка, меняющая наклон ножа, 10-12 - механизм микроподачи

\section{Последовательность обработки материала} при приготовлении постоянных препаратов:

1. Подготовка материала к фиксации.

2. Фиксация материала водными или спиртовыми фиксаторами в зависимости от вида приготавливаемых препаратов.

3. Промывка материала.

4. Обезвоживание.

5. Пропитывание материала растворителями парафина.

6. Пропитывание парафином.

7. Заливка материала в парафин.

8. Изготовление блоков из материала, пропитанного парафиHOM.

9. Приготовление срезов с помощью микротома.

10. Наклейка срезов на предметное стекло.

11. Просушивание наклеенных препаратов в термостате.

12. Удаление парафина из срезов ксилолом, толуолом. 
13. Удаление ксилола из срезов спиртом.

14. Удаление спирта из срезов дистиллированной водой.

15. Протравливание срезов квасцами.

16. Окрашивание препаратов.

17. Обезвоживание окрашенных препаратов спиртом.

18. Замещение спирта в срезах ксилолом.

19. Наклейка покровного стекла канадским бальзамом (заключение срезов в канадский бальзам).

20. Просушивание срезов и подчистка.

21. Этикетирование препаратов.

22. Изучение под микроскопом.

Выполнение данной лабораторной работы требует составления календарного плана!

\section{I. Фиксация материала}

С целью умертвления объекта с сохранением его прижизненной структуры проводится фиксация объекта (корешки, стебли, листья) в фиксаторе Левитского (хромовая кислота 1\% + формалин 10\% в равных соотношениях по 2,5мл.). Размер объектов 0,5-0,7 cм.

\section{II. Приготовление блоков (методом закапывания)}

Выплавить объект из парафиновой заливки горячей препаровальной иглой, приклеить на кончик иглы. Поверхность деревянного держателя нагреть над спиртовкой и при помощи парафиновой палочки на теплую поверхность нанести каплю жидкого парафина, затем без перерыва следующую и т.д., пока возвышение будет 3 - 4 мм. Приготовленный заранее объект перенести на возвышение и подогретой иглой установить вертикально (корешок устанавливают чехликом вверх). Продолжить закапывание горячим парафином, пока над объектом слой парафина не будет равен 3 мм.

Опустить блок в холодную воду, после остывания его обрезать лезвием безопасной бритвы в форме правильного параллелепипеда, снять сверху лишний парафин, так чтобы остался слой 2 мм.

\section{III. Приготовление микротомных срезов}

Приготовить микротомные срезы толщиной в 10 микрон, при этом ленту с ножа следует снимать мягкой кисточкой и укладывать на чёрную бумагу в чашку Петри блестящей стороной вверх.

\section{IV. Наклейка парафиновых срезов на предметное стекло}

Предметное стекло положить на трафарет. На поверхность 
предметного стекла из капельницы нанести несколько капель дистиллированной воды и распределить её по месту покровного стекла. Лента укладывается на место покровного стекла перпендикулярно длинной стороне предметного стекла блестящей стороной к воде. Над пламенем спиртовки, осторожно подогревая, расправить сморщенные парафиновые срезы. После расправления срезов излишки воды удалить фильтровальной бумагой.

\section{План приготовления препарата:}

1. Подготовка материала к фиксации (проращивание луковицы и т.д.) - 1-3 суток.

2. Фиксирование материала (водный фиксатор) - 24 часа.

3. Промывка в проточной воде - 1-3 часа.

4. Обезвоживание материала (выдерживание в спиртовых растворах).
a) спирт $20 \%$
б) спирт $40 \%$ по 30 мин. в каждом
в) спирт $60 \%$
г) спирт $80 \%$.

В $80 \%$ спирте материал можно оставить на ночь или на более продолжительный срок.

5. Полное обезвоживание материала

a) спирт $96 \% 1$ час

б) спирт $96 \%$-1час

в) спирт $100 \%$ - 1 час

г) спирт $100 \%$ - 1 час

6. Замещение спирта на растворитель парафина

a) 1 часть ксилола +3 части спирта -1 час.

б) ксилол + спирт 1:1 - 1 час.

в) ксилол + спирт 3:1 - 1 час.

г) ксилол 1 - 1 час.

д) ксилол 2 -1 час.

7. Добавляем в ксилол парафин до полного насыщения (с избытком) - 10 мин.

8. Помещаем смесь в термостат в закрытом сосуде при $56-57^{\circ} \mathrm{C}$ для пропитывания материала смесью парафина и ксилола - 1 сут. (можно и дольше).

9. Открываем крышку сосуда для испарения ксилола (до исчезновения запаха ксилола) - 3-6 сут. 
10. Остужаем сосуд с парафином и извлекаем «Пряник» - 10 мин. материал, залитый в парафин можно хранить долго.

11. Изготовление блока - 15 мин.

12. Получение срезов на микротоме - 10 мин.

13. Наклеивание ленты на предметное стекло - 10 мин.

14. Просушивание препарата при $40^{\circ} \mathrm{C}$ не менее 12 час (можно при выключенном термостате хранить долго).

15. Удаление парафина со срезов: обмываем срезы ксилолом из капельницы и ставим стекло на 30 мин. в ксилол.

16. Переносим стекло в свежий ксилол на 5 мин.

17. Удаление ксилола со срезов: обмываем срезы $96 \%$ спиртом из капельницы и ставим стекло на 5 мин в $96 \%$ спирт.

18. Промываем стекла в трех сменах дистиллированной воды по 5 мин.

19. Протравливание (для лучшего окрашивания материала) 4- 6 час в растворе $4 \%$ железоаммонийных квасцов.

20. Промывка в двух сменах дистиллированной воды по 5 мин.

21. Окрашивание: в растворе гематоксилина (0,1-1\%) - 12 час (можно на ночь).

22. Промывка в воде -15 мин.

23. Дифференцировка (удаление лишнего красителя) срезов в $2 \%$ растворе железоаммонийных квасцов - 5 мин.

24. Промывка препарата в воде - 30 мин.

25. Обезвоживание окрашенных срезов:

$96 \%$ спирт - 10 мин.

$100 \%$ спирт - 10 мин.

26. Удаление спирта:

ксилолом I - 10 мин.;

ксилолом II - 10 мин.

27. Заключение в бальзам - наклейка покровных стекол - 5 мин.

28. Сушка препаратов - 3 суток.

29. Наклеивание этикеток на стекла с препаратами - 5 мин.

\section{Вопросы для обсуждения:}

1. Опишите устройство микротома.

2. Перечислите типы микротомов, дополнительное оборудование к ним.

3. Опишите последовательность действий при приготовлении постоянных микропрепаратов. 


\section{ЛАБОРАТОРНАЯ РАБОТА № 6}

\section{Тема: «Перевод временных препаратов в постоянные»}

Цель работы: освоить технику перевода временных препаратов в постоянные.

\section{Материалы, оборудование, реактивы:}

1. Лед

2. Чашки Петри

3. Скальпели

4. Предметные и покровные стекла

5. Жидкость Гойера

6. Спирт этиловый

7. Толуол

8. Кислота уксусная

9. Канадский бальзам

10. Вода дистиллированная

\section{Самостоятельная работа студентов:}

1. Ознакомиться со способами перевода временных препаратов в постоянные.

2. Осуществить перевод временных препаратов в постоянные с помощью уксусной кислоты.

Часто временные давленые препараты бывают настолько хорошими, что их можно оставлять на более длительный срок. Существует несколько способов сохранения временных препаратов и перевода их в постоянные. Самым простым из них является нанесение расплавленного парафина на края покровного стекла, которым, заполняя просвет между ним и предметным стеклом, значительно снизит испарение жидкости, окружающей объект. Такие препараты сохраняются в течение нескольких недель, а иногда и месяцев. Вместо расплавленного парафина для окантовки временных препаратов используют клей БФ или лак для ногтей, которые наносят кисточкой по периметру покровного стекла.

Значительно удлиняется срок хранения временных препаратов при погружении объектов в глицерин, который замещает среду, окружавшую их раньше. Замена среды осушествляется таким образом: у одного из краев покровного стекла фильтровальной бумагой оттягивают жидкость, имевшуюся в препарате, одновременно на противоположный конец наносится новая среда, которая легко 
проникает под стекло и способствует вытеснению прежней. Испарение глицерина настолько невелико, что объекты в нем могут сохраняться годами, особенно при окантовке стекла парафином.

Перевести временные препараты в полупостоянные можно и другим способом. Стараясь не сдвинуть с места объект, осторожно снимают покровное стекло, препарат обезвоживают 96 \%-м спиртом, затем бутиловым спиртом, проводят через ксилол и заключают в канадский бальзам. Для снятия покровного стекла широко используют метод замораживания объекта путем использования твердой углекислоты (сухой лед), жидкого азота или термоэлектрического охладителя микротома.

Если нет сухого льда, жидкого азота или термоэлектрического охлаждающего столика (ТОС), можно воспользоваться более простой методикой для отделения покровных стекол. В чашку Петри наливают 10\%-ю уксусную кислоту, кладут две спички (с которых предварительно отламывают серные головки) и на них помещают препарат покровным стеклом вниз. Через 10- 15 мин покровное стекло отделяется. Предметное стекло с монослоем быстро опускают в фиксатор (уксусный алкоголь на 45\%-й уксусной кислоте), затем в 96- и 100\%-й спирты, ксилол и заключают в канадский бальзам.

Существуют способы перевода временных препаратор в постоянные без удаления покровного стекла. Для этого с одной стороны покровного стекла последовательно наносят, а с противоположной стороны отсасывают при помощи фильтровальной бумаги следующие растворы: 45\%-я уксусная кислота, смесь 96\%-го спирта с 45\%-й уксусной кислотой (3:1), 96\%-й спирт, 100\%-й спирт, 300\%й спирт + ксилол $(1: 1)$, ксилол и бальзам.

Постоянные препараты, содержащие монослой клеток, можно получить, раздавливая материал в среде, способной долгое время сохранять окраску объекта. В качестве такой среды для раздавливания и заключения объекта можно использовать смесь Гойера, которая мацерирует и просветляет объект благодаря хлоралгидрату и сохраняет его благодаря гуммиарабику.

Если препараты необходимо оставить неокрашенными, их обычно заключают в глицерин-желатину. Это наиболее простой и быстрый способ изготовления постоянного препарата. Однако он не предназначен для окрашенных препаратов, так как глицеринжелатина обладает обесцвечивающим свойством. 
При приготовлении постоянных препаратов на предметное стекло следует нанести жидкость Гойера.

\section{Жидкость Гойера:}

50 мл воды

30 г гуммиарабика

16 мл глицерина

200 г хлоралгидрата

При отсутствии гуммиарабика его можно заменить камедью вишни. Просушенную камедь тщательно растирают в ступке, заливают дистиллированной водой на 30 мин., затем кипятят на водяной бане 5 минут. После добавления в нее глицерина и хлоралгидрата смесь фильтруют несколько раз через батист, затем ее помещают в темный, плотно закрывающийся сосуд и хранят в холодильнике.

При переводе временных препаратов в постоянные необходимо удалить покровное стекло, провести препарат через серию спиртов и заключить в канадский бальзам.

Удалить покровное стекло можно двумя способами:

1. Предметное стекло помещается на совершенно ровную поверхность сухого льда или на столик замораживающего микротома, или на плоский конец алюминиевого стержня, вставленного в сосуд с жидким азотом. Препарат замораживают от 30 до 90 секунд. Затем скальпелем или лезвием бритвы снимают покровное стекло.

2. Придерживая стекло, осторожно снимают парафин, которым стекло было окаймлено. Затем препарат кладут на спички в чашку Петри покровным стеклом вниз. В чашку Петри предварительно наливают $10 \%$ уксусную кислоту. Покровное стекло отделяется от предметного через 10 - 15 мин., но в некоторых случаях может держаться до суток.

Объект исследования, оставшийся на предметном стекле, должен быть обезвожен и заключен в канадский бальзам. Для этого на предметное стекло переносят:

1. В смесь 96 \%спирта и $45 \%$ уксусной кислоты в отношении 1:1 на 5-10 мин.

2. Спирт $96 \%-3$ мин.

3. Спирт $96 \%-1-2$ мин.

4. Спирт $100 \%-3$ мин.

5. Спирт $100 \%-3$ мин. 
6. Смесь толуол : спирт $100 \%(1: 1)-5$ мин.

7. Толуол -3 мин.

8. Толуол -3 мин.

Затем на препарат наносится чистый толуол, капается канадский бальзам и препарат покрывается чистым покровным стеклом.

Вопросы для обсуждения:

1. Опишите способы перевода временных препаратов в постоянные.

2. Перечислите основные действия, необходимые для перевода временных препаратов в постоянные. 


\section{ВОПРОСЫ К ПРАКТИЧЕСКИМ ЗАНЯТИЯМ}

\section{Практическое занятие № 1 (2 часа)}

Тема: Цели и задачи микротехники

\section{Вопросы для обсуждения:}

1. Микротехника в цитологии и гистологии: методы наблюдения.

2. Микротехника в физиологии растений: установки для культивирования растений в контролируемых условиях.

3. Микротехника в анатомии: изготовление анатомических срезов.

4. Методы получения временных препаратов.

5. Методы получения постоянных препаратов.

\section{Литература:}

1. Бавтуто Г.А., Ерей Л.М. Практикум по анатомии и морфологии растений: Учеб. пособие для студентов биологич. спец. вузов. Мн.: Новое знание, 2002.

2. Барыкина Р.П. Справочник по ботанической микротехнике. Основы и методы. - М.: зд-во МГУ, 2004.

3. Верещагина В. А. Основы общей цитологии: учеб. пособие для студентов вузов, обучающихся по спец. и направлению подгот. «Биология»/В.А. Верещагина. - М.: Академия, 2009.

4. Кузнецов С.Л., Мушкамбаров Н.Н. Гистология, цитология и эмбриология: учеб. для мед. вузов. - М.: Мед. информ. агентство, 2007.

\section{Практическое занятие № 2 (2 часа)}

Тема: Основы световой микроскопии. Принципы работы микроскопа

Вопросы для обсуждения:

1. Широкопольная (светлопольная) микроскопия.

2. Темнопольная микроскопия.

3. Фазово-контрастная микроскопия.

4. Интерференционная микроскопия.

5. Флуоресцентная микроскопия.

6. Конфокальная микроскопия.

7. Инфракрасная микроскопия.

8. Микроскопия в отраженном свете. 


\section{Литература:}

1. Барыкина Р.П. Справочник по ботанической микротехнике. Основы и методы. - М.: зд-во МГУ, 2004.

2. Справочник по микробиологическим и вирусологическим методам исследования/Под ред. М.О. Биргера. -2-е изд., испр. и доп. М.: Медицина, 1973.

3. Теппер Е.3. Практикум по микробиологии: учеб. пособие для вузов по спец. «Микробиология» и биолог.спец.-5-е изд., перераб. и доп .- М.: Дрофа, 2004.

\section{Практическое занятие № 3 (2 часа)}

Тема: Техника изготовления микропрепаратов

\section{Вопросы для обсуждения:}

1. Химическая фиксация тканей:

- Альдегиды;

- Соли неорганических кислот;

- Органические кислоты;

- Спирты;

- Ацетон;

- Фиксирующие смеси.

2. Физические методы фиксации:

а. Замораживание образцов ткани;

b. Сублимационная дегидратация тканей;

3. Изготовление микротомных препаратов.

\section{Литература:}

1. Бавтуто Г.А., Ерей Л.М. Практикум по анатомии и морфологии растений: Учеб. пособие для студентов биологич. спец. вузов. Мн.: Новое знание, 2002.

2. Барыкина Р.П. Справочник по ботанической микротехнике. Основы и методы. - М.: зд-во МГУ, 2004.

3. Кузнецов С.Л., Мушкамбаров Н.Н. Гистология, цитология и эмбриология: учеб. для мед. вузов. - М.: Мед. информ. агентство, 2007.

4. Справочник по микробиологическим и вирусологическим методам исследования/Под ред. М.О. Биргера. -2-е изд., испр. и доп. М.: Медицина, 1973.

5. Теппер Е.3. Практикум по микробиологии: учеб. пособие для вузов по спец. «Микробиология» и биолог.спец.-5-е изд., перераб. и доп .- М.: Дрофа, 2004. 


\section{Практическое занятие № 4 (2 часа)}

Тема: Основы гистохимии.

\section{Вопросы для обсуждения:}

1. Гистохимия как наука. История развития гистохимии.

2. Классификация методов гистохимии.

3. Гистохимические реакции:

- Красители, поглощающие свет в видимой области спектра;

- Флуоресцентные красители;

- Реакции с ионами тяжелых металлов;

- Реакции с использованием окислительно-восстановительных индикаторов.

4. Комплексные гистохимические технологии. Иммуногистохимия.

5. Физические методы в гистохимии: ультрафиолетовая и ультрафиолетовая флуоресцентная микроскопия.

\section{Литература:}

1. Барыкина Р.П. Справочник по ботанической микротехнике. Основы и методы. - М.: зд-во МГУ, 2004.

2. Красильников А.П., Романовская Т.Р. Микробиологический словарь-справочник.-2-е изд.,доп.и перераб.-Минск:Асар, 1999.

3. Основы микробиологии, вирусологии, иммунологии: учеб. по предмету «Микробиология, вирусология и иммунология» по различ. спец. сред. мед. и фармацевт. образования/ под ред. А. А. Воробьева, В.В. Зверева. -3-е изд., перераб. и доп. - М.: Академия, 2009.

4. Справочник по микробиологическим и вирусологическим методам исследования/Под ред. М.О. Биргера. -2-е изд., испр. и доп. М.: Медицина, 1973.

\section{Практическое занятие № 5 (2 часа)}

Тема: Методы определения полового хроматина

Вопросы для обсуждения:

1. Уровни упаковки хроматина.

2. Структурно-функциональная организация хромосом.

3. Эухроматин и гетерохроматин.

4. Структура политенных хромосом и хромосом типа «ламповых щеток».

5. Кариотип человека. 
6. Определение пола на основе цитологического исследования клеток плоского эпителия полости рта человека.

\section{Литература:}

1. Верещагина В. А. Основы общей цитологии: учеб. пособие для студентов вузов, обучающихся по спец. и направлению подгот. «Биология»/В.А. Верещагина. - М.: Академия, 2009.

2. Кузнецов С.Л., Мушкамбаров Н.Н. Гистология, цитология и эмбриология: учеб. для мед. вузов. - М.: Мед. информ. агентство, 2007.

3. Николенко В.Н., Сперанский В.С. Анатомия человека с элементами гистологии: учеб. для студентов вузов, обучающихся по спец. «Сестринское дело» и «Гигиена». - М.: Академия, 2008. 


\section{ОРГАНИЗАЦИЯ САМОСТОЯТЕЛЬНОЙ РАБОТЫ СТУДЕНТОВ}

\section{Виды и формы деятельности студентов \\ в рамках самостоятельной работы}

Целью самостоятельной работы студентов является овладение фундаментальными знаниями, профессиональными умениями и навыками деятельности по профилю, опытом творческой, исследовательской деятельности.

Методика контроля и оценки качества выполнения студентами самостоятельной работы на практических занятиях осуществляется:

- беглым опросом теоретических положений с выставлением оценки;

- проверкой домашних заданий и конспекта по теории, вынесенной на самостоятельную проработку.

Самостоятельная работа студентов запланирована в объеме 72 часа и включает в себя конспектирование литературы по разделам рабочей программы дисциплины и самостоятельное дополнительное повторение разделов.

Контрольные сроки выполнения самостоятельной работы - первая декада декабря.

Каждый студент обязан следующим образом отчитаться по самостоятельной работе, предъявив конспекты предложенных тем.

В качестве контроля самостоятельной работы может быть использовано тестирование или собеседование по конспектам. 


\section{МЕТОДИЧЕСКИЕ РЕКОМЕНДАЦИИ \\ К РАЗЛИЧНЫМ ВИДАМ САМОСТОЯТЕЛЬНОЙ РАБОТЫ}

Тема 1 «Краткая история развития микротехнических изобретений».

В конспекте необходимо раскрыть следующие положения:

1. Развитие биологической оптики: изобретение и совершенствование микроскопа.

2. Применение анилиновых красителей в гистохимии и совершенствование методов окрашивания.

3. Развитие люминисцентной гистохимии.

4. Выявление белков при помощи меченных антител и развитие иммуноцитохимии.

5. Электронная микроскопия и ее значение в современной биологии.

Основная литература:

1. Барыкина Р.П. Справочник по ботанической микротехнике. Основы и методы. - М.: зд-во МГУ, 2004.

2. Мурадов С.В. Учебно-методическое пособие по курсу «Микробиология» :для вузов по спец. 011600 «Биология». - Петропавловск-Камч.: Изд-во КамГУ, 2007.

3. Теппер Е.3. Практикум по микробиологии: учеб. пособие для вузов по спец. «Микробиология» и биолог.спец.-5-е изд., перераб. и доп .- М.: Дрофа, 2004.

Тема 2 «Техника изготовления гистологических препаратов».

В конспекте необходимо раскрыть следующие положения:

1. Взятие материала для изготовления гистологических препаратов.

2. Умерщвление экспериментальных животных.

3. Вскрытие лабораторных животных.

4. Взятие и этикетирование материала.

Основная литература:

1. Волкова О.В., Елецкий Ю.К. Основы гистологии с гистологической техникой. 2-е изд. - М.: Медицина, 1982. 
2. Козлов Н.А. Общая гистология: ткани домашних млекопитающих животных: учеб. пособие для вузов по спец. «Ветеринария». - СПб.: Лань, 2004.

3. Кузнецов С.Л., Мушкамбаров Н.Н. Гистология, цитология и эмбриология: учеб. для мед. вузов. - М.: Мед. информ. агентство, 2007.

\section{Тема 3 «Микротомы и работа с ними».}

В конспекте необходимо раскрыть следующие положения:

1. Санный микротом.

2. Ротационный микротом.

3. Замораживающий микротом с термоэлектрическим охлаждающим стоилком.

4. Уход за микротомом.

5. Микротомные ножи и правила резания на микротоме.

6. Ультратом.

Основная литература:

1. Бавтуто Г.А., Ерей Л.М. Практикум по анатомии и морфологии растений: Учеб. пособие для студентов биологич. спец. вузов. Мн.: Новое знание, 2002.

2. Барыкина Р.П. Справочник по ботанической микротехнике. Основы и методы. - М.: зд-во МГУ, 2004.

3. Волкова О.В., Елецкий Ю.К. Основы гистологии с гистологической техникой. 2-е изд. - М.: Медицина, 1982.

Тема 4 «Приготовление препаратов для эмбриологических исследований в ботанике».

В конспекте необходимо раскрыть следующие положения:

1. Исследование пыльцы и пыльцевых трубок.

2. Исследование зародышевых мешков и эндосперма на тотальных препаратах.

3. Выращивание растительного зародыша на искусственной среде.

Основная литература:

1. Бавтуто Г.А., Ерей Л.М. Практикум по анатомии и морфологии растений: Учеб. пособие для студентов биологич. спец. вузов. Мн.: Новое знание, 2002.

2. Барыкина Р.П. Справочник по ботанической микротехнике. Основы и методы. - М.: зд-во МГУ, 2004. 
Тема 5 «Выявление грибов и бактерий в органах высших растений».

В конспекте необходимо раскрыть следующие положения:

1. Основные красители для мицелия грибов и бактерий.

2. Обнаружение грибов-паразитов и бактерий в тканях высших растений.

3. Обнаружение мицелия грибов в древесине.

4. Выявление микоризы и бактероидной ткани в корнях высших растений.

Основная литература:

1. Бавтуто Г.А., Ерей Л.М. Практикум по анатомии и морфологии растений: Учеб. пособие для студентов биологич. спец. вузов. Мн.: Новое знание, 2002.

2. Барыкина Р.П. Справочник по ботанической микротехнике. Основы и методы. - М.: зд-во МГУ, 2004.

\footnotetext{
Тема 6 «Специальные методы исследования растительных объектов».

В конспекте необходимо раскрыть следующие положения:

1. Споро-пыльцевой анализ.

2. Исследования эпидермы и кутикулы.

3. Мацерация.

Основная литература:
}

1. Бавтуто Г.А., Ерей Л.М. Практикум по анатомии и морфологии растений: Учеб. пособие для студентов биологич. спец. вузов. Мн.: Новое знание, 2002.

2. Барыкина Р.П. Справочник по ботанической микротехнике. Основы и методы. - М.: зд-во МГУ, 2004.

\section{Тема 7 «Выявление элементов нервной системы».}

В конспекте необходимо раскрыть следующие положения:

1. Импрегнация элементов макроглии (астроцитов).

2. Импрегнация элементов микроглии.

3. Выявление нервных элементов методом прижизненного окрашивания метиленовым синим.

Основная литература:

1. Антипчук Ю.П. Гистология с основами эмбриологии: учеб. пособие для студентов пед. ин-тов по биолог.спец. - М.: Просвещение, 1983. 
2. Волкова О.В., Елецкий Ю.К. Основы гистологии с гистологической техникой. 2-е изд. - М.: Медицина, 1982.

3. Козлов Н.А. Общая гистология: ткани домашних млекопитающих животных: учеб. пособие для вузов по спец. «Ветеринария». - СПб.: Лань, 2004.

4. Николенко В.Н., Сперанский В.С. Анатомия человека с элементами гистологии: учеб. для студентов вузов, обучающихся по спец. «Сестринское дело» и «Гигиена». - М.: Академия, 2008.

\section{Тема 8 «Применение изотопов в микротехнике».}

В конспекте необходимо раскрыть следующие положения:

1. Метод авторадиографии.

2. Метод иммунофлуоресценции.

Основная литература:

1. Справочник по микробиологическим и вирусологическим методам исследования/Под ред. М.О. Биргера. -2-е изд., испр. и доп. М.: Медицина, 1973. 


\section{ИТОГОВЫЙ ТЕСТ ПО ДИСЦИПЛИНЕ}

1. Какие требования предъявляются к гистологическим препаратам?

а. Исследуемая ткань должна сохранять свое прижизненное строение

b. Срез должен быть прозрачным и тонким

c. Изучаемые структуры должны отчетливо выделяться на общем фоне препарата

d. Все ответы верные

2. Каким образом обеспечивается выделение определенных микроструктур препарата на общем фоне?

a. Правильной фиксацией

b. Качественной обработкой срезов

c. Соответствующей окраской

d. Взятием материала путем биопсии

3. Какой способ получения гистологического материала является наименее предпочтительным для изучения прижизненного состояния микроструктур?

а. Получение материала от животных, умерщвленных для этих целей

b. Получение материала от животных в результате биопсии

c. Взятие материала от трупа

4. Что такое фиксация?

а. Сохранение в обрабатываемом материале того строения, которое он имел при жизни

b. Заливка препарата в емкости для хранения

c. Приготовление микропрепаратов на предметных стеклах

5. Каким требованиям должна отвечать фиксирующая жидкость (укажите 2 варианта)?

а. Должна быть прозрачной

b. Должна быстро проникать в ткани

c. не должна вызывать грубых нарушений тканевых структур

d. должна одинаково воздействовать на различные структуры ткани

6. Каких правил необходимо придерживаться при фиксации гистологического материала? Укажите НЕПРАВИЛЬНЫЕ утверждения (2 варианта ответа). 
а. Размер кусочков зависит от диффузионной способности фиксирующих жидкостей

b. Количество фиксирующей жидкости должно не менее чем в 2 раза превышать объем исследуемого материала

с. Фиксируемый объект нужно помещать так, чтобы фиксирующая жидкость проникала с одной стороны

d. Необходимо соблюдать время фиксации

е. О завершении процесса фиксации свидетельствуют равномерная окраска и одинаковая консистенция тканей на поверхности разреза материала

7. Укажите простые фиксаторы (2 варианта ответа)

a. Формалин

b. Ацетон

c. Жидкость Буэна

d. Жидкость Карнуа

8. Чем сложные фиксаторы отличаются от простых?

a. Сложно приготовить

b. Процесс фиксации идет долго

c. Состоят из смеси различных веществ

d. Сложный набор операций при фиксации

9. Чем смягчают твердые растительные объекты для их фиксации? Укажите неправильный ответ.
а. Глицерином
b. Кипячением
c. Формалином
a. М.С. Навашиным
b. Л.Ф. Бюркартом
c. М.Н. Прозиной

10. Кем был предложен метод темпоральной фиксации?

11. Какая структура растительной клетки относится к стабильным структурам по отношению к воздействию фиксаторов?
а. Ядро
b. Клеточная стенка
c. Митохондрии

12. В каком случае нельзя включать этиловый спирт в состав фиксатора для растительного материала?
a. В случае фиксации ядра
b. В случае фиксации аппарата Гольджи и митохондрий
c. В случае фиксации митохондрий и пластид 
13. Каковы положительные свойства хромовой кислоты как фиксатора? (2 варианта ответа).

a. Сохраняет строение ядра и цитоплазмы

b. Служит протравой для клеточных структур

c. Окрашивает цитоплазму в оранжевый цвет

d. После фиксцией хромовой кислотой структуры хорошо окрашиваются кармином

14. Укажите фиксатор, не относящийся к водным.

a. Фиксатор Навашина

b. Фиксатор Флемминга

c. Фиксатор Модилевского

d. Фиксатор Карнуа

15. Каков состав фиксатора Карнуа?

a. Этиловый спирт, хлороформ, уксусная кислоты

b. Этиловый спирт, ледяная уксусная кислота

c. Этиловый спирт, формалин, ледяная уксусная кислоты

16. Каким правилом пользуются при приготовлении спиртов заданной концентрации?

a. Правилом Навашина

b. Правилом Леви

c. Правилом Менделеева

17. Швейцеровский реактив, реактив Манжэна, анилиновые красители применяются для выявления:

а. Пектиновых веществ

b. Целлюлозы

c. Лигнина

18. Какие фиксаторы используются для фиксации митохондрий и пластид?

a. Фиксатор Флемминга, фиксатор Германа

b. Фиксатор Левитского, смесь Гаммалунда

c. Фиксатор Навашина, фиксатор Карнуа

19. Для чего производится промывка материала?

а. Для удаления загрязнителей

b. Для удаления излишка фиксатора

c. Для удаления красителя

20. Что представляет собой гистологическая батарея?

а. Последовательный ряд сосудов со спиртами различных концентраций

b. Батарея отопления в гистологической лаборатории 
с. Последовательный ряд сосудов с фиксаторами

d. Последовательный ряд сосудов со $96 \%$ спиртом

21. Укажите недостатки заливка материала в парафин (2 варианта ответа).

a. Значительное сжатие исследуемого материала

b. Долгое время заливки

c. Ограниченное время хранения блоков

$\mathrm{d}$. Необходимость удаления парафина перед окраской

22. Какие требования предъявляются к материалу перед заливкой?

а. препарат должен быть обезвожен и окрашен

b. препарат должен быть обезвожен и не содержать спирт

c. препарат должен быть определенной температуры и не содержать спирт

d. препарат должен быть обезвожен и содержать спирт

23. Для чего используется микротом?

а. Для приготовления срезов определенной толщины

b. Для окраски срезов

c. Для микроскопирования

24. Для получения хороших срезов на микротоме главными требованиями являются: (2 варианта ответа)

a. Выбор правильного угла наклона ножа

b. Выбор правильной толщины ножа

c. Выбор правильного угла резания

d. Выбор правильного места прикрепления среза

25. Какие части микроскопа относятся к механической части? (2 варианта ответа).
a. Тубус
b. Микрометрический винт
c. Конденсор
d. Окуляр
е. Объектив

26. Для чего используется конденсор?

a. Усиливает освещенность препарата

b. Придает свету лампы синий цвет

c. Увеличивает резкость

27. Какие объективы используются с маслом?
a. Сухие
b. Иммерсионные 
с. Влажные

28. Что не входит в состав осветительной части микроскопа?

a. Источник света

b. Коллектор

c. Конденсор

d. Предметный столик

29. Увеличение объектива равно 40, увеличение окуляра равно 10 , чему равно общее увеличение системы?
a. 50
b. 400
c. 200

30. Какая маркировка наносится на объектив масляной иммерсии?

a. Черная полоса по фронтальной части объектива

b. Белая полоса по фронтальной части объектива

c. Зеленая маркировка

31. Какой маркировкой обозначаются объективы для работы только с покровным стеклом?

a. 0

b. 0,17

32. Рассмотрите изображение микроскопа. Что изображено под номером 10 ?

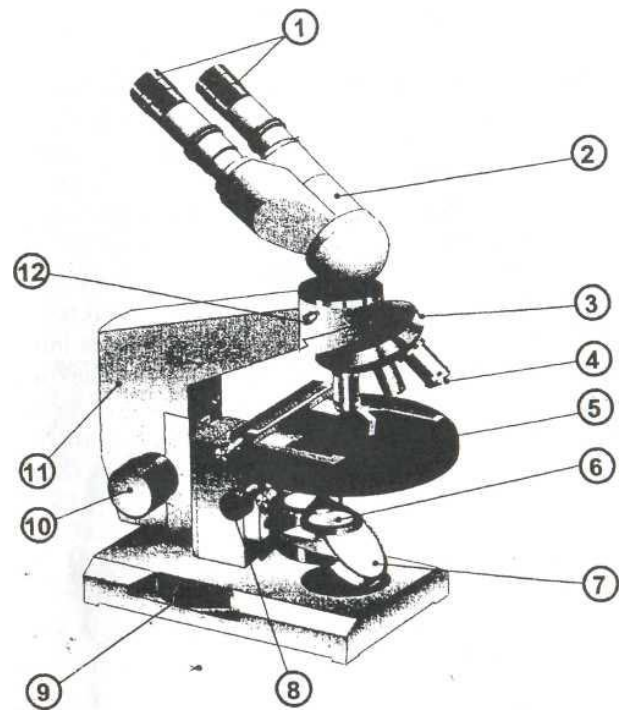



а. Конденсор
b. Макровинт
c. Тубусодержатель

33. Какая среда может использоваться для прижизненного микроскопирования объектов?
а. Вода
b. Формалин
c. Этиловый спирт

34. Сколько линз в окуляре микроскопа?
a. 1
b. 2
c. 3

35. Какой физический закон лежит в основе метода микроскопии в темном поле?
а. Эффект Тиндаля
b. Принцип Кёллера
c. Корпускулярная теория света

36. Для чего применяется сканирующий электронный микроскоп?

а. Для получения сверхчеткого изображения

b. Для получения объемного изображения

c. Для исследования функционально-морфологических изменений клеток

37. Рассмотрите изображение микроскопа. Укажите осветительную часть. (2 варианта ответа)

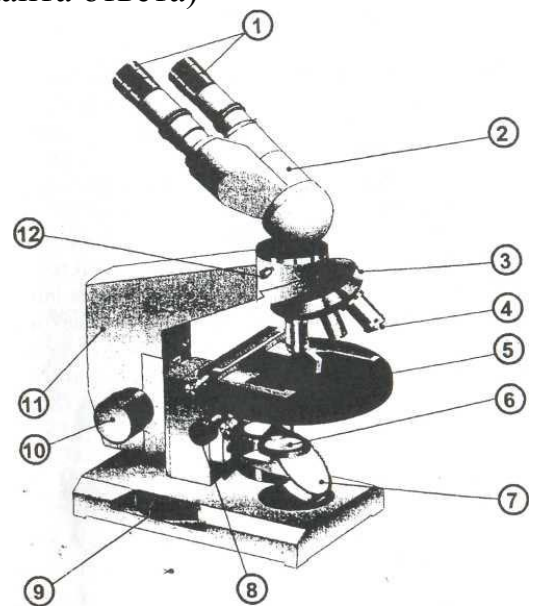


a. Окуляры -(1)

b. Зеркало - (7)

c. Конденсор - (6)

d. Объектив - (4)

е. Револьверная насадка - (3)

38. Укажите объекты, которые возможно микроскопировать в природной среде без предварительного препарирования? (2 варианта ответа).

а. Одноклеточные водоросли

b. Яйцеклетка млекопитающего

c. Клетки дрожжей

d. Нейроны

39. Что представляют из себя камеры Ранвье?

а. Предметные стекла, на которых вышлифованы углубления со сферической поверхностью

b. Невысокие цилиндрики, приготовленные из стеклянной трубки с диаметром до 1,5 см со шлифованными основаниями

с. Предметные стекла с перегородками

40. В каких ботанических исследованиях может применяться метод инфильтрации тканей?

а. В цитологических

b. В анатомических

c. В цитофизиологических

41. В основе метода ИФА лежит:

a. реакция антиген-антитело

b. реакция вирус-лейкоцит

c. реакция коагуляции белка

42. По типу иммунохимического взаимодействия выделяют методы ИФА: ( 2 варианта ответа).

а. Неконкурентный метод

b. Рекомбинантный метод

c. Конкурентный метод

d. Пептидный метод

43. При прямом конкурентном методе ИФА иммобилизованными на твердой фазе являются:
a. Антигены
b. Антитела
c. Ферменты 
44. При непрямом конкурентном методе ИФА иммобилизованными на твердой фазе являются:
a. Антигены
b. Антитела
c. Ферменты

45. В рекомбинантных иммуноферментных тест-системах используются:

а. Нативные антигены, подвергшиеся мутации

b. Полученные генно-инженерным способам белки-аналоги определенных антигенов

с. Химические синтезированные фрагменты белков

46. В зависимости от того, какие антигены используются в иммуноферментных тест-системах, выделяют следующие группы: (укажите неверный ответ).
а. Лизатные
b. Вирусные
c. Рекомбинантные
d. Пептидные

47. На основании электролитических свойств среди красителей выделяют следующие группы (укажите неправильный ответ).
а. Основные красители
b. Кислотные красители
c. Нейтральные красители
d. Красители-электролиты

48. Назовите специфическую цветную реакцию на крахмал.

a. Йодная реакция

b. Реакция Молиша

c. Реакция с серно-кислой медью

49. Какие утверждения НЕ ОТНОСЯТСЯ к основным красителям? (2 варианта ответа).

a. Основной краситель - это красящее основание или его соль

b. Основной краситель окрашивает клеточные и тканевые структуры основной природы

с. Окрашивающиеся тканевые компоненты характеризуются базофилией

d. Окрашивающиеся тканевые компоненты характеризуются оксифилией П

е. Хорошо окрашивает хроматин и ядрышко 
50. Какие утверждения относятся к кислотным красителям (2 вариант ответа).

a. Кислотный краситель - это красящая кислота или ее соль

b. Окрашивает частицы кислотной природы

c. К кислотным красителям относятся эозин, эритрозин, конго красный

d. Окрашивающиеся тканевые компоненты характеризуются базофилией

51. Прижизненное окрашивание применяется для:

a. Определения $\mathrm{pH}$ внутриклеточных структур

b. Для дифференциации морфологически однородных, но функционально различающихся клеток

с. Для исследования проницаемости цитоплазмы

d. Все ответы верны

52. Использование красителей относится к:

а. Цитологическим методам исследования

b. Цитохимическим методам исследования

c. Гистологическим методам исследования

53. По оптическим свойствам красители бывают:

а. Флуоресцентные

b. Преломляющие

c. Ахроматические

54. Что представляет собой прямое окрашивание?

a. Окрашивание объекта непосредственно в растворе красителя

b. Окрашивание объекта после предварительного протравливания

с. Окрашивание нефиксированного объекта

d. Окрашивание обезвоженного объекта

55. Для чего применяется дифференцированное окрашивание?

а. Для выявления определенных клеточных и тканевых элементов

b. Для окрашивания разными цветами

c. Для получения общего ориентировочного представления об изучаемом объекте

56. Какой метод применяется для окраски жгутиков микроорганизмов?

a. Метод Леффлера

b. Метод Бурри

c. Метод Пешкова 
57. По каким показателям можно определить, что клетки изучаемого материала живы? (2 варианта ответа).

а. Активное движение цитоплазмы

b. Способность к плазмолизу

c. Свечение цитоплазмы

d. Наличие ядра

58. Для чего используются проционовые красители?

а. Для выявления мертвых и живых клеток

b. Для окраски ядра и хроматина

c. Для окраски цитоплазмы и вакуолей

59. При витальном окрашивании растительного материала основными красителями в нейтральной среде хорошо окрашивается:
а. Ядро
b. Вакуоли
c. Цитоплазма

60. Каким простым способом можно определить, кислотный краситель или основной?
а. По цвету раствора
b. По диффузии на полоске фильтровальной бумаги
c. По температуре кипения 


\section{ПРИМЕРНЫЕ ВОПРОСЫ К ЗАЧЕТУ}

1. Фиксация клеток и тканей, способы, методика.

2. Гистохимическая окраска: назначение и разновидности.

3. Методы выявления нуклеиновых кислот в клетке.

4. Способы повышения плотности тканей.

5. Основные этапы парафинирования тканей.

6. Основные этапы депарафинирования тканей.

7. Временные препараты. Их назначение.

8. Постоянные препараты. Их назначение.

9. Настройка системы освещения микроскопа по Келлеру.

10. Хроматическая и сферическая абберации при микроскопии.

11. Маркировка окуляров и объективов. Ее назначение.

12. Измерения при помощи микроманипулятора микроскопа.

13. Методика окраски полового хроматина.

14. Методика окраски крахмалсодержащих структур.

15. Строение микроскопа и его использование.

16. Типы микроскопов.

17. Люминисцентная микроскопия.

18. Работа с иммерсионными объективами. Оптическое назначение иммерсии.

19. Общие правила обращения, настройки и ухода за микроскопом.

20. Средства документирования микроскопических наблюдений.

21. Оптический микрометр и объект-микрометр.

22. Микроманипуляторы. Их назначение.

23. Виды иммерсионных жидкостей.

24. Особенности эксплуатации санного микротома.

25. Особенности эксплуатации роторного микротома.

26. Назначение ультрамикротома.

27. Способы определения уровня кислотно-щелочного равновесия жидкостей.

28. Клиническая центрифуга. Ее устройство и назначение.

29. Камера Горяева для подсчета эритроцитов. Ее устройство и назначение.

30. Гематологический счетчик. Его назначение.

31. Колориметры фотоэлектрические и сравнительные. 


\section{БИБЛИОГРАФИЧЕСКИЙ СПИСОК}

1. Антипчук Ю.П. Гистология с основами эмбриологии: учеб. пособие для студентов пед. ин-тов по биолог.спец. - М.: Просвещение, 1983.

2. Асонов Н.Р. Микробиология: Учеб. для вузов. -4-е изд., перераб. и доп. - М.: Колос, 2001.

3. Бавтуто Г.А., Ерей Л.М. Практикум по анатомии и морфологии растений: Учеб. пособие для студентов биологич. спец. вузов. - Мн.: Новое знание, 2002.

4. Бакулина Н.А. Микробиология: Учеб. для мед. училищ. - М.: Медицина, 1980.

5. Барыкина Р.П. Справочник по ботанической микротехнике. Основы и методы. - М.: зд-во МГУ, 2004.

6. Верещагина В. А. Основы общей цитологии: учеб. пособие для студентов вузов, обучающихся по спец. и направлению подгот. «Биология»/В.А. Верещагина. - М.: Академия, 2009.

7. Волкова О.В., Елецкий Ю.К. Основы гистологии с гистологической техникой. 2-е изд. - М.: Медицина, 1982.

8. Гусев М.В. Микробиология. - М.: Академия, 2008.

9. Гусев М.В., Минеева Л.А. Микробиология: учеб. для вузов по спец. «Биология». -8-е изд., стереотип. - М.: Академия, 2008.

10. Заварзин Г.А. Введение в природоведческую микробиологию. - М.: Университет, 2001.

11. Козлов Н.А. Общая гистология: ткани домашних млекопитающих животных: учеб. пособие для вузов по спец. «Ветеринария». - СПб.: Лань, 2004

12. Красильников А.П., Романовская Т.Р. Микробиологический словарь-справочник.-2-е изд.,доп.и перераб.-Минск:Асар, 1999.

13. Кузнецов С.Л., Мушкамбаров Н.Н. Гистология, цитология и эмбриология: учеб. для мед. вузов. - М.: Мед. информ. агентство, 2007.

14. Мурадов С.В. Учебно-методическое пособие по курсу «Микробиология» :для вузов по спец. 011600 «Биология». - Петропавловск-Камч.: Изд-во КамГУ, 2007.

15. Назарова М.Н., Гаврилов И.А., Багрянская Н.А. Практическое пособие к большому практикуму по цитологической и эмбриологической микротехнике. Часть 1. Техника изготовления микротомных и давленых препаратов. - Воронеж, 2002. 
16. Нетрусов А.И., Котова И.Б. Микробиология: учеб. для вузов по направлению подготовки бакалавра «Биология» и биол. спец. 2-е изд., стер. - М.: Академия, 2007.

17. Николенко В.Н., Сперанский В.С. Анатомия человека с элементами гистологии: учеб. для студентов вузов, обучающихся по спец. «Сестринское дело» и «Гигиена». - М.: Академия, 2008.

18. Основы микробиологии, вирусологии, иммунологии: учеб. по предмету «Микробиология, вирусология и иммунология» по различ. спец. сред. мед. и фармацевт. образования/ под ред. А. А. Воробьева, В.В. Зверева. -3-е изд., перераб. и доп. - М.: Академия, 2009.

19. Практикум по микробиологии / Под ред. А.И. Нетрусова. М.: Академия, 2005.

20. Практикум по микробиологии: учеб. пособие для вузов/под ред. А.И.Нетрусова. - М.: Академия, 2005.

21. Пяткин К.Д. Микробиология (с вирусологией и иммунологией): учебник для студентов мед. ин-тов. -4-е изд., перераб. и доп. - М.: Медицина, 1981.

22. Справочник по микробиологическим и вирусологическим методам исследования/Под ред. М.О. Биргера. -2-е изд., испр. и доп. - М.: Медицина, 1973.

23. Теппер Е.3. Практикум по микробиологии: учеб. пособие для вузов по спец. «Микробиология» и биолог.спец.-5-е изд., перераб. и доп .- М.: Дрофа, 2004.

24. Экология микроорганизмов: Учеб. для ун-тов по спец. «Микробиология»/Под ред.А.И. Нетрусова. - М.: Академия, 2004. 
Для заметок 
Для заметок 
Для заметок 
Учебное издание

Мурадов Сергей Васильевич

Девятова Елизавета Александровна

Головина Татьяна Петровна

\title{
ЛАБОРАТОРНЫЙ ПРАКТИКУМ ПО ДИСЦИПЛИНЕ «МИКРОТЕХНИКА»
}

\author{
Учебно-методическое пособие \\ Чебоксары, 2019 г.
}

Редактор С.В. Мурадов

Компьютерная верстка и правка T.В. Яковлева

Дизайн обложки Н.B. Фирсова

Подписано в печать 24.09.2019 г. Дата выхода издания в свет 26.09.2019 г.

Формат 60×84/16. Бумага офсетная. Печать офсетная.

Гарнитура Times. Усл. печ. л. 4,8825. Заказ К-532. Тираж 500 экз.

Издательский дом «Среда» 428005, Чебоксары, Гражданская, 75

+7 (8352) 655-731

info@phsreda.com

www.phsreda.com

Отпечатано в Студии печати «Максимум»

428005, Чебоксары, Гражданская, 75

+7 (8352) 655-047

info@maksimum21.ru

www.maksimum21.ru 